УДК 574.474

СИСТЕМА ВЗГЛЯДОВ О.В. СМИРНОВОЙ В ЛЕСНОЙ БИОГЕОЦЕНОЛОГИИ (C) 2019 г. О.И. Евстигнеев ${ }^{1,3^{*}}$, В.Н. Коротков ${ }^{2}$

${ }^{1}$ Заповедник «Брянский лес», Россия, 242180, Брянская обл., ст. Нерусса

${ }^{2}$ Институт глобального климата и экологии имени академика Ю. А. Израэля, Россия, 107258, Москва, ул. Глебовская, 20Б

${ }^{3}$ Центр по проблемам экологии и продуктивности лесов РАН, Россия, 117997 Москва, ул.

Профсоюзная, 84/32, стр. 14

*E-mail:quercuseo@mail.ru

Поступила в редакцию 16.09.2019

О.В. Смирнова - профессор, доктор биологических наук, крупный ученый в области демографии растений, популяционной биологии и лесной биогеоценологии. Система взглядов О.В. Смирновой построена на представлениях о ведущей роли популяций растений и животных в организации биогеоценотического покрова. При этом подразумевается, что непрерывный оборот поколений в популяциях эдификаторов (ключевых видов) необходимое условие для поддержания видового и структурного разнообразия сообществ, а также для обеспечения их устойчивости. Эта система взглядов сформировалась под влиянием идей профессора А.А. Уранова. Развитие этих представлений было последовательным и постепенным. Сначала О.В Смирнова изучает биологию видов растений разных жизненных форм, их индивидуальное развитие, в котором выделяет онтогенетические состояния, необходимые для демографических исследований, затем - разрабатывает теорию ценопопуляций как надорганизменных систем, способных к самоподдержанию в различных условиях, и, наконец, - развивает учение популяционной организации биогеоценозов и создает концепцию антропогенной трансформации лесного покрова в голоцене. Все это помогает понять механизмы формирования современной зональности, которые обусловлены деятельностью человека.

Ключевые слова: биологический возраст растений, популячионная стратегия растений, ценопопулячия, эдификатор, лесная биогеоченология, современная зональность, историческая экология

9 октября 2019 г. отмечает юбилей Ольга Всеволодовна Смирнова - профессор, доктор биологических наук, крупный ученый в области демографии растений, популяционной биологии и лесной биогеоценологии (рис. 1).

О.В. Смирнова родилась в семье служащих в 1939 году. Мама - Нина Николаевна, переводчица с французского языка, папа - Всеволод Михайлович, инженер. Дедушка по материнской линии - Жуков Николай Алексеевич, окончил Московское высшее коммерческое училище (ныне Финансовая академия), работал экономистом в Наркомате иностранных дел. Дедушка по отцовской линии - Смирнов Михаил Иванович, закончил отделение Московского археологического института в Нижнем Новгороде, выдающийся историк-краевед, в 1919 году основал Переславль-Залесский историко-архитектурный и художественный музей- 
заповедник. Детство О.В. Смирновой прошло в Гагаринском переулке в центре Москвы (Жукова, 2006).

Интерес к биологии у Ольги Всеволодовны появился в школьные годы в кружке юннатов при Всероссийском обществе охраны природы (ВООП), которым руководил Петр Петрович Смолин. В 1963 году О.В. Смирнова окончила кафедру геоботаники МГУ им. М.В. Ломоносова. В 1968 году защитила кандидатскую диссертацию под руководством проф. А.А. Уранова на тему: «Жизненные циклы, численность и возрастной состав популяций основных компонентов травяного покрова дубрав». В 1983 году защитила докторскую диссертацию на тему: «Поведение видов и функциональная организация травяного покрова широколиственных лесов (на примере равнинных широколиственных лесов Европейской части СССР и липняков Сибири)». С 1966 по 1992 год О.В. Смирнова - сотрудник Проблемной биологической лаборатории (ПБЛ) при Московском государственном педагогическом институте им. В.И. Ленина (МГПИ) (рис. 2, 3). В 1987 году по итогам кандидатской и докторской диссертаций выходит книга «Структура травяного покрова широколиственных лесов». С 1 сентября 1992 года О.В. Смирнова работает в Центре по проблемам экологии и продуктивности лесов (ЦЭПЛ РАН) в должности главного научного сотрудника. С 1993 по 2008 год - преподавала в Пущинском государственном университете (ПущГУ) на кафедре Системной экологии, которую организовал и возглавил проф. А.С. Комаров (рис. 4, 5). В 1994 году под редакцией О.В. опубликована коллективная монография «Восточноевропейские широколиственные леса», а в 2004 году - книга в двух томах «Восточноевропейские леса: история в голоцене и современность». В 2017 г. по заказу редакции «Plant and Vegetation» в издательстве Springer вышел переработанный вариант этой книги «European Russian Forests: Their Current State and Features of Their History». В основе научных работ О.В., начиная с юннатского кружка и по настоящее время, лежат ежегодные исследования в экспедициях (рис. $6-8)$.

В 2015 году О.В. Смирнова создает международный научный журнал «Russian Journal of Ecosystem Ecology». Издание освещает вопросы функционирования и динамики экосистем, организации биогеоценотического покрова и другие проблемы экологии. Под руководством О.В. Смирновой защищено 25 кандидатских диссертаций (Сугоркина, 1989; Евстигнеев, 1990; Аргунова, 1993; Истомина, 1993; Коротков, 1993; Недосеко, 1993; Чумаченко, 1993; Киселева, 1994; Шаниязова, 1994; Баринова, 1997; Рипа, 1997; Самохина, 1997; Сарычева, 2000; Бобровская, 2001; Браславская, 2001; Турубанова, 2002; Бобровский, 2004; Шестакова, 2005; Богданова, 2006; Романовский, 2006; Луговая, 2008; Попов, 2008; Алейников, 2010; Запрудина, 2012; Харитоненков, 2012), пятеро учеников стали докторами наук (Чумаченко, 2006; Аргунова, 2010; Евстигнеев, 2010; Бобровский, 2013; Недосеко, 2018). 2 декабря 1994 г. 
присвоено звание профессора по специальности «Ботаника». К настоящему моменту О.В. Смирнова опубликовала свыше 290 работ. Все публикации, в т.ч. полный библиографический список, размещены в Интернете на странице http://istina.msu.ru/profile/sov1933/.

В основе биогеоценотических взглядов О.В. Смирновой лежат представления о популяционной организации живого, которые сформировались под влиянием ее учителя проф. А.А. Уранова (Шорина и др., 2014). В рамках этой системы взглядов О.В. Смирнова внесла существенный вклад в развитие концепций биологического возраста растений и популяционной стратегии растений, в создание теории ценопопуляций и популяционной организации биогеоценозов, а также в формирование представлений о современной зональности как антропогенном явлении.

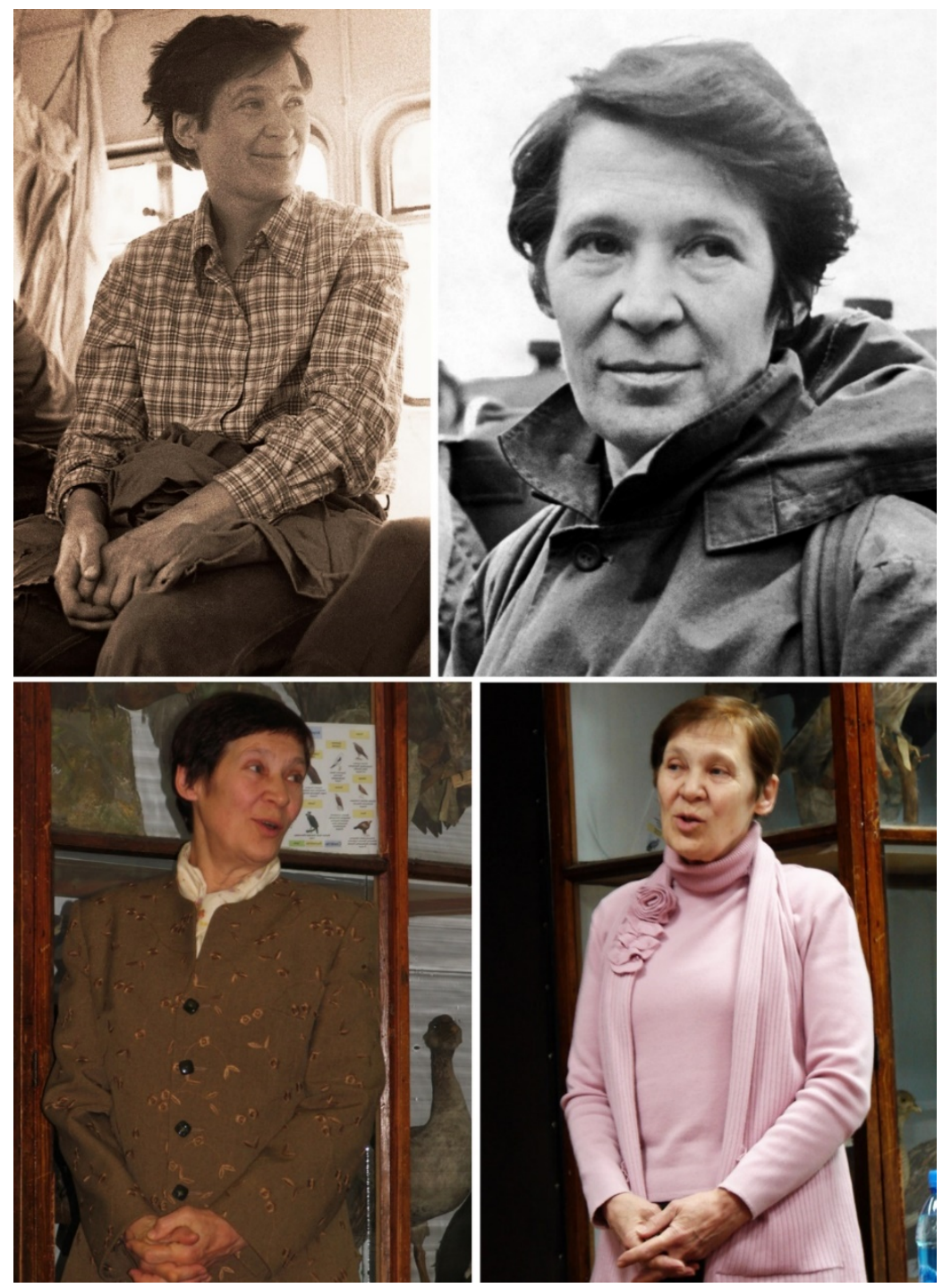

Рисунок 1. Смирнова О.В. Слева вверху. Во время экспедиции в Сабаре в августе 1979 года, Средний Урал, Артинский район Свердловской области. Фотография О.Г. Баринова. Справа вверху.

Перед поездкой в Сабар в 1991 году. Фотография М.А Бариновой. Слева внизу. На защите кандидатской диссертации Натальи Евгеньевны Богдановой в МПГУ, 20 ноября 2006 г. Справа внизу. На защите кандидатской диссертации Екатерины Львовны Железной в МПГУ, 2 марта 2009 г. Фотография О.М. Железного 

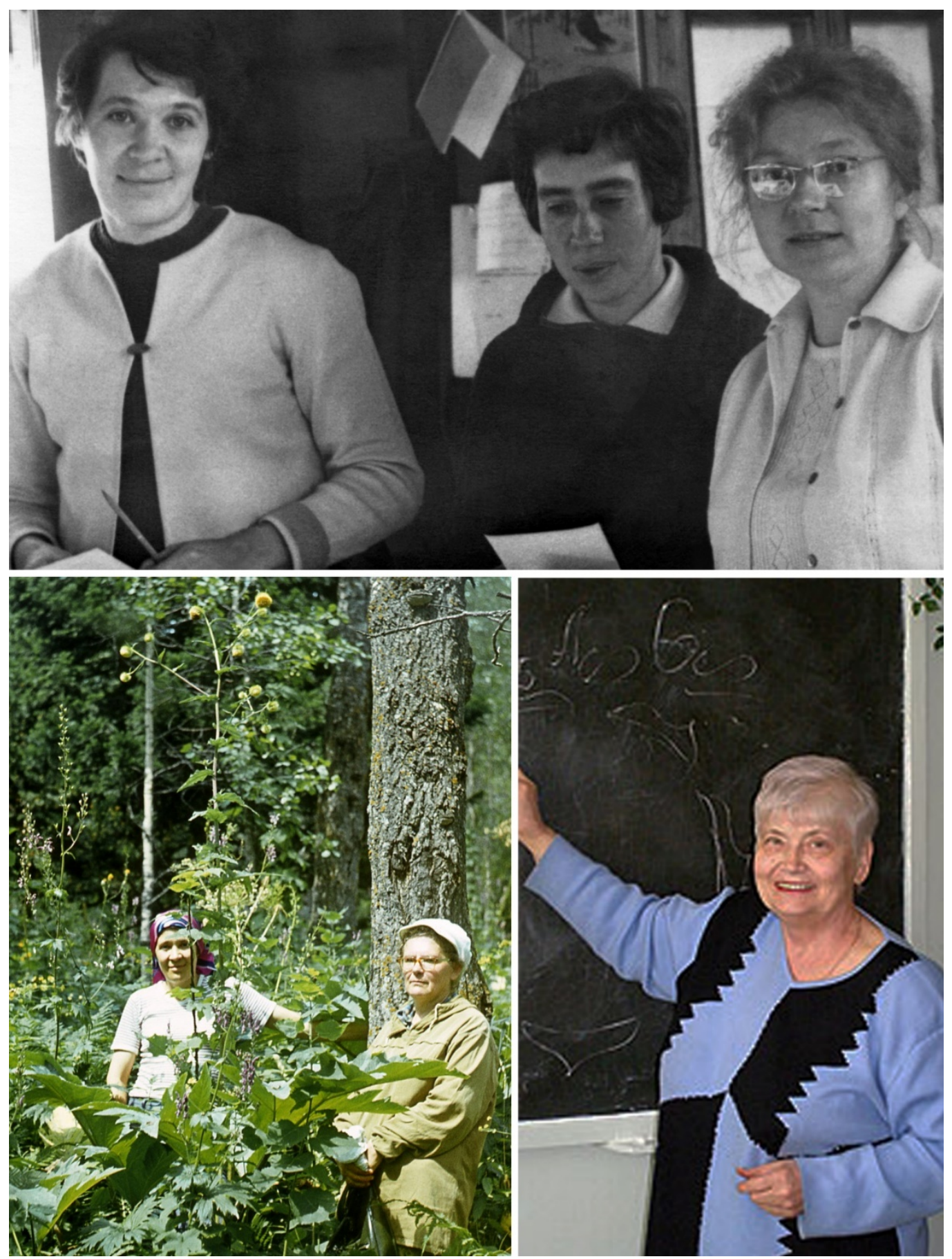

Рисунок 2. Коллеги О.В. Смирновой (начало). Вверху. О.В. Смирнова с ученицами Алексея Александровича Уранова - с Ермаковой Инной Михайловной (научный сотрудник ПБЛ МГПИ им. В.И. Ленина) и с Григорьевой Ниной Михайловной (преподаватель кафедры ботаники МГПИ, справа) в 1974 году. Слева внизу. Среди лесного высокотравья с Татьяной Ивановной Серебряковой (зав. кафедрой ботаники МГПИ с 1974 по 1986 гг.) во время поездки на Салаир (Гурьевский район

Кемеровской области) в 1982 году. Фотография М.А. Бариновой. Справа внизу. Александра Александровна Чистякова (к.б.н., профессор кафедры ботаники, физиологии и биохимии растений Пензенского университета), с которой написаны основные работы по популяционной организации лесных сообществ 


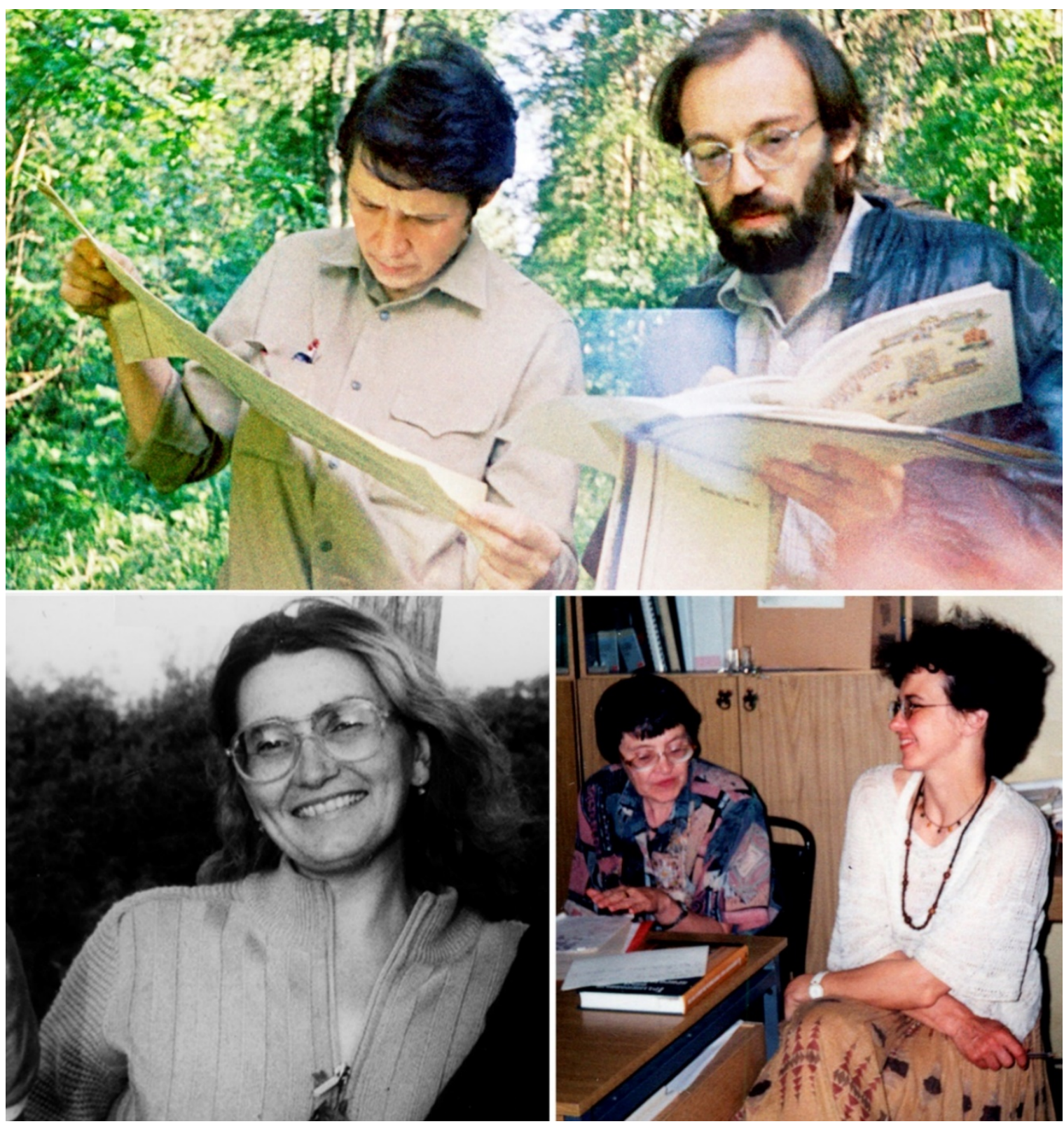

Рисунок 3. Коллеги О.В. Смирновой (продолжение). Вверху. С Попадюком Романом Васильевичем (научный сотрудник ПБЛ МГПИ) во время экспедиции в Приокско-Террасном заповеднике в 1990 году. Фотография М.А. Бариновой. Внизу слева. Торопова Наталья

Александровна (к.б.н., доцент кафедры ботаники Тамбовского пединститута) в Каневском заповеднике (Черкасская обл., Украина) в 1983 году. Внизу справа. Коллеги О.В. Смирновой обсуждают научные планы в лаборатории Моделирования экосистем ИФХиБПП РАН (г. Пущино).

Слева - Заугольнова Людмила Борисовна (д.б.н., г.н.с. ЦЭПЛ РАН, г. Москва), справа - Ханина Лариса Геннадьевна (к.б.н., доцент, зав. лабораторией Вычислительной экологии ИМПБ РАН, г. Пущино). 1999 г.

\section{Концепция биологического возраста у растений}

Основа популяционно-демографических исследований - разделение популяций растений на онтогенетические (возрастные) группы. Трудами Т.А. Работнова (1950) и его последователями, в т. ч. О.В. Смирновой, обоснован и развит подход к возрастной дифференциации особей, основанный на изучении онтогенеза организмов от рождения до смерти. Этот метод предусматривает выделение в индивидуальном развитии растений этапы 
- онтогенетические состояния, которые отражают биологический возраст особи. О.В. Смирнова изучила онтогенез более 30 видов растений Восточноевропейских лесов и липняков Западной Сибири (табл. 1). Первые описания онтогенезов О.В. Смирнова представила в трех коллективных монографиях, которые вышли под редакцией проф. А.А. Уранова: «Онтогенез и возрастной состав популяций цветковых растений» (1967), «Вопросы морфогенеза цветковых растений и строения их популяций» (1968) и «Возрастной состав популяций цветковых растений в связи с их онтогенезом» (1974).

В этих работах показано, что для демографических исследований определение онтогенетического (возрастного) состояния имеет несравненно большее значение, чем анализ календарного возраста. Это обусловлено двумя причинами: 1) разные особи одного вида часто достигают одноименного онтогенетического состояния в различные календарные сроки, но поскольку они находятся на одном и том же этапе развития, то их роль в популяции и в сообществе одинакова; 2) особи разных видов и жизненных форм могут проходить одни и те же онтогенетические состояния в течение разного времени. Все это означает, что сравнительную оценку роли растений в ценозе логичнее связывать не с календарным возрастом, а с уровнем их развития - онтогенетическим состоянием.

Таблица 1. Онтогенезы растений, которые изучила О.В. Смирнова

\begin{tabular}{|c|c|}
\hline Жизненные формы & Названия растений \\
\hline Длиннокорневищные травы & $\begin{array}{c}\text { Aegopodium podagraria L., Carex pilosa Scop., } \\
\text { Mercurialis perennis } \mathrm{L} \text {. }\end{array}$ \\
\hline Короткокорневищные травы & $\begin{array}{c}\text { Anemone altaica Fisch. Ex C.A. Mey., A. coerulea D.C., A. } \\
\text { nemorosa L., A. ranunculoides L., Asarum europaeum L., } \\
\text { Carex sylvatica Huds., Dentaria bulbifera L., D. } \\
\text { quinguefolia Bleb., Lamium maculatum (L.) L., Pulmonaria } \\
\text { obscura Dumort., Lathyrus vernus (L.) Bernh., } \\
\text { Viola mirabilis L. }\end{array}$ \\
\hline Луковично-корневищные травы & $\begin{array}{l}\text { Allium victorialis L., Erythronium sibiricum } \\
\text { (Fisch et Mey) Kryl. }\end{array}$ \\
\hline Луковичные травы & $\begin{array}{l}\text { Allium ursinum L., Gagea erubescens (Bess.) Schult. \& } \\
\text { Schult. Fil., G. granulosa Turcz., G. lutea (L.) Ker-Gawl., } \\
\text { G. minima (L.) Ker-Gawl., Scilla bifolia L., S. sibirica Haw, } \\
\text { Tulipa biebersteiniana } \text { Schult. \& Schult. Fil. }\end{array}$ \\
\hline Клубневые травы & $\begin{array}{l}\text { Corydalis bracteata (Steph.) Pers., C. bulbosa (L.) DC., } C \text {. } \\
\text { cava (L.) Schweigg. \& Koerte, C. marschalliana } \\
\text { (Pall. Ex Willd.) Pers. }\end{array}$ \\
\hline $\begin{array}{c}\text { Подстилочно-наземно-ползучие } \\
\text { травы }\end{array}$ & $\begin{array}{c}\text { Galeobdolon luteum Huds., Galium odoratum (L.) Scop., } \\
\text { Stellaria holostea L., Viola odorata L. }\end{array}$ \\
\hline Кистекорневые травы & Ficaria verna Huds. \\
\hline Стержнекорневые травы & Alliaria 6etiolate (Bieb.) Cavara \& Grande \\
\hline Деревья & Fagus sylvatica L. \\
\hline
\end{tabular}

Примечание. Часть онтогенезов изучена в соавторстве, см. страницу в Интернете на странице http://istina.msu.ru/profile/sov1933/ 


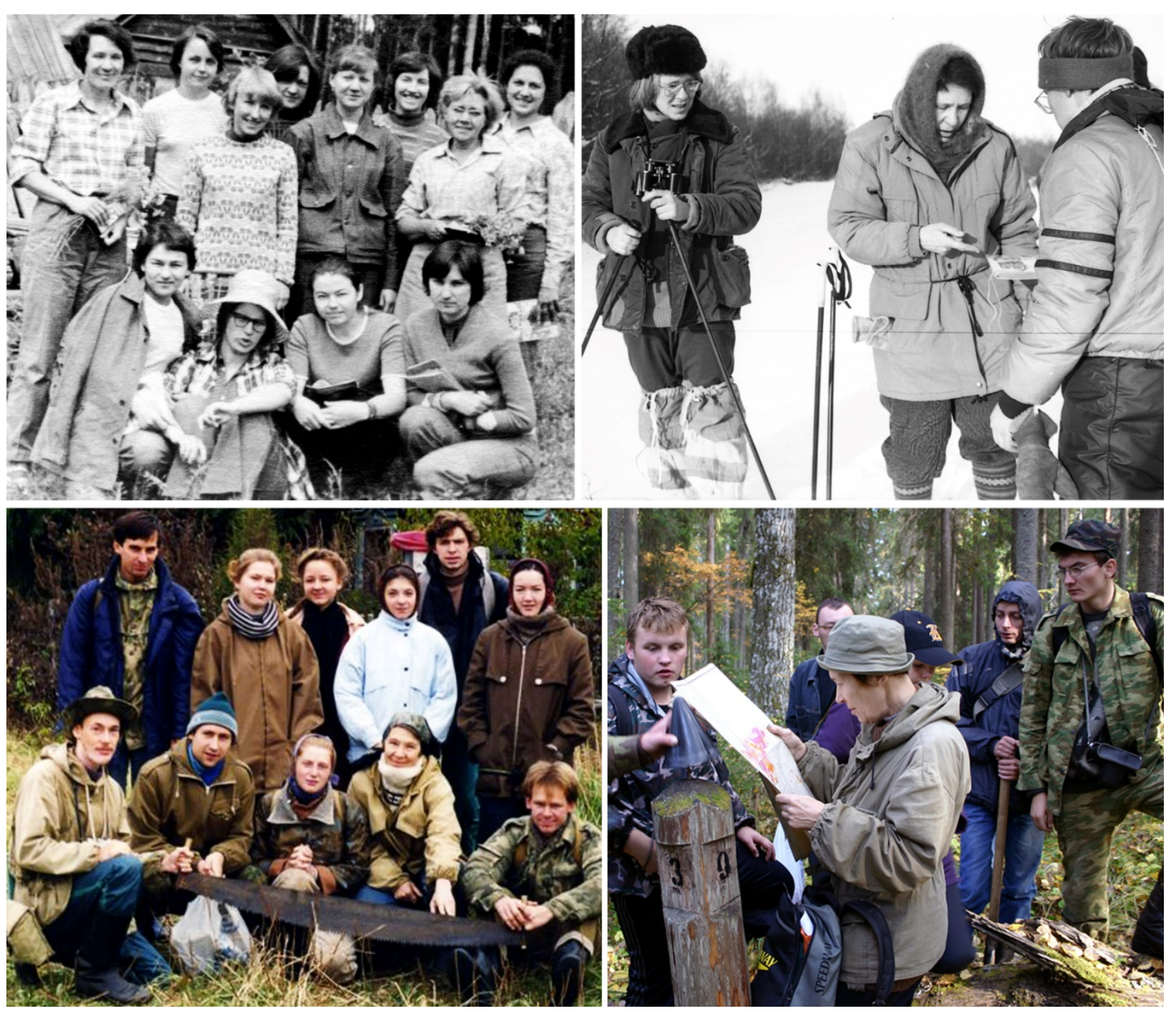

Рисунок 4. Полевые практики. Вверху слева. Летняя практика со студентами 2 курса МГПИ в 1977 году с О.В. Смирновой (к.б.н., стоит слева) и с Мариной Петровной Соловьевой (доцент, к.б.н., стоит вторая справа) в Теллермановском лесничестве (Воронежская обл.). Вверху справа. Зимняя практика с магистрантами Пущинского ун-та в Центрально-Лесном заповеднике в 1994 году: Беляков Константин Викторович (магистрант, слева), Смирнова О.В., Романов Михаил Сергеевич (магистрант, справа). Фотография М.А. Бариновой. Внизу слева. Осенняя практика с магистрантами

первого курса Пущинского ун-та в заповеднике "Калужские засеки" в 1996 году. Стоят слева направо: Коротков Владимир Николаевич (к.б.н., с.н.с. Всероссийского научно-исследовательского центра по лесным ресурсам), Синотова Оксана (магистрантка), Мищенко Марина (магистрантка), Тарасова Лариса (магистрантка), Бобровский Максим Викторович (ст. преподаватель). Сидят слева

направо: Курицын Александр (магистрант), Тимофеев Владимир (магистрант), Агафонова

Александра (аспирантка), Смирнова О.В., Егоров Алексей (магистрант). Внизу справа. Осенняя практика с магистрантами первого курса Пущинского ун-та в национальном парке «Русский север» в 2005 году. Слева направо: Алейников Алексей, Харитоненков Максим, Смирнова О.В., Кобозева Екатерина, Шанин Владимир, Горнов Алексей. Фотография М.В. Бобровского.

\section{Концепция популяционной стратегии растений}

О.В. Смирнова, опираясь на систему представлений о ценотипах растений, предложенную Л.Г. Раменским (1935), и концепцию типов стратегий, разработанную Дж. Граймом (1979), обосновала новый подход к изучению типов популяционных стратегий 
(популяционного поведения) у растений (Смирнова, 1980, 1987; Смирнова, Чистякова, 1980). Основные положения этого подхода следующие.

1. В качестве интегральных, фитоценотически значимых свойств популяционных стратегий видов рассматриваются: конкурентоспособность, фитоценотическая толерантность и реактивность. Конкурентоспособность (виолентность, конкурентная мощность) способность видов создавать и контролировать среду в сообществе, а также подавлять другие организмы вследствие высокой энергии жизнедеятельности и большой интенсивности использования среды. Фитоценотическая толерантность (патиентность, устойчивость, выносливость к крайне неблагоприятным фитоценотическим условиям) - умение видов длительно существовать на территории, занятой другими организмами, за счет максимального снижения энергии жизнедеятельности. Реактивность (эксплерентность, динамичность, пионерность, рудеральность) - склонность видов к максимально быстрому освоению освободившихся ресурсов в сообществе благодаря энергичному вегетативному росту и значительному репродуктивному усилию.

Согласно этим определениям, популяционная стратегия растений - это способность видов господствовать или занимать подчиненное положение в сообществе, которая выработалась в результате длительной эволюции в доагрикультурных климаксовых ценозах, ненарушенных человеком. Охарактеризованные популяционные стратегии отражают фитоценотические потенции вида. Реальное положение вида в конкретном ценозе - это его фитоценотические позиции. Наиболее полного совпадения фитоценотических потенций и позиций следует ожидать в климаксовых сообществах доагрикультурного времени. Реальное положение вида в современных сообществах существенно отличается от его роли в климаксовых ценозах, поскольку структура сообществ коренным образом преобразована человеком.

2. Интегральные свойства (конкурентоспособность, фитоценотическая толерантность, реактивность) присущи каждому виду, но выражены они в разной степени. Виды, у которых преобладает конкурентоспособность, относятся к конкурентным, толерантность - к толерантным, а реактивность - к реактивным. Кроме групп видов, характеризующихся этими тремя типами стратегий (поведения), вслед за Дж. Граймом (1979), О.В. Смирнова выделяет группы видов, занимающих промежуточное положение.

3. Изучение стратегий основывается на исследовании биологических свойств видов. Это положение предполагает дифференцированный подход к изучению биологических (поведенческих) и экологических свойств видов. Познание экологических свойств выявляет требования видов к ресурсам среды, а изучение биологических особенностей - способ и характер использования этих ресурсов. Другими словами, экологические свойства растений 
определяют видовой состав сообщества, а биологические - главенствующую или подчиненную роль видов в сообществе. Этот подход к выявлению типов поведения у растений существенно отличается от способов изучения ценотипов, предложенных Л.Г. Раменским (1935), и типов стратегий, разработанных Дж. Граймом (1979). Так, патиенты Раменского (или стресс-толеранты Грайма) выделяются на основе экологических свойств видов, в то время как виоленты (конкурентные виды) и эксплеренты (рудеральные виды) - на основе биологических.

4. История изучения фитоценотических потенций у растений показала, что нельзя выделить какой-то единственный, независимый от других признак, который определял бы полностью тип поведения растений. При этом каждый тип поведения растений характеризуется комплексом частных (дифференциальных) свойств, которые представляют собой конкретные проявления конкурентоспособности, толерантности и реактивности.

5. Анализ типов поведения целесообразно проводить у растений близких жизненных форм, занимающих одну пространственно-временную нишу и относящихся к одному трофическому уровню, т.е. принадлежащих одной синузии (Смирнова, 1987). Это определяется тем, что виды одной синузии характеризуются сходным влиянием на окружающую среду и выполняют близкую роль в сообществе. Кроме того, биологическое своеобразие видов наиболее полно проявляется при одновременном исследовании всей исторически сформировавшейся совокупности видов. В лесах умеренной зоны в качестве таковых обычно рассматривают синузии деревьев, кустарников, летнего широкотравья, ранневесенних эфемероидов (Восточноевропейские ..., 1994).

Опираясь на эти положения и детальное изучение биологических свойств растений, О.В. разработала классификацию видов по типам стратегий (поведения) в синузиях весенних эфемероидов и летнего широкотравья (Смирнова, 1987). Этот подход успешно реализован при изучении типов стратегии деревьев и кустарников Восточноевропейских лесов (Смирнова, Чистякова, 1980; Евстигнеев, 2004, 2010; Евстигнеев, Диденко, 2004). Ниже в качестве примера приводим классификацию растений по типам поведения в синузии летнего широкотравья (Смирнова, 1987).

І тип. Конкурентные виды

1-я группа - вегетативно-подвижные: Aegopodium podagraria L., Convallaria majalis L., Carex pilosa Scop., Mercurialis perennis L.

II тип. Толерантные виды

1-я группа - вегетативно-малоподвижные: Asarum europaeum L., Carex digitata L., C. rhizina Blytt ex Lindbl., Paris quadrifolia L., Polygonatum multiflorum (L.) All., Pulmonaria obscura Dumort., Viola mirabilis L.

2-я группа - вегетативно-неподвижные: Brachypodium sylvaticum (Huds.) Beauv., Bromopsis benekenii (Lange) Holub, Carex sylvatica Huds., Campanula latifolia L., C. rapunculoides L., C. trachelium L., Dactylis glomerata L., Festuca gigantea (L.) Vill., F. sylvatica 
L., Geum urbanum L., Melica nutans L., Lathyrus vernus (L.) Bernh., Poa nemoralis L., Ranunculus cassubicus L., Scrophularia nodosa L., Scutellaria altissima L.

III тип. Реактивные виды

1-й подтип - конкурентнореактивные. 1-я группа - вегетативно-подвижные: Ajuga genevensis L., A. reptans L., Galeobdolon luteum Huds., Milium effusum L., Viola odorata L. 2-я группа - вегетативно-неподвижные: Lamium maculatum (L.) L.

О.В. Смирнова показала, что выяснение фитоценотических потенций у растений, позволяет понять некоторые особенности в организации ценозов климаксного типа, которые отличались максимальным видовым разнообразием (Смирнова, Чистякова, 1980; Смирнова, 1983, 1987). Стабильную основу каждой из синузий составляли конкурентные виды, они господствовали по численности и биомассе, вовлекали наибольшую порцию вещества и энергии в сообщество, существенно изменяли ценотическую среду и играли роль эдификаторов. Толерантные виды, существуя на предельно низком уровне жизненности, использовали ресурсы, которые не удалось освоить конкурентно мощным растениям. Реактивные виды «кочевали» от одного нарушения к другому и «штопали» дырки, периодически возникающие в сообществе на месте гибели особей в популяциях эдификаторов. Виды с разными типами стратегии (поведения) выступают как комплементарные образования, благодаря которым наиболее полно используются ресурсы сообщества.

\section{Теория ценопопуляций растений}

Коллектив проблемной биологической лаборатории при МГПИ, сотрудником которой в то время была О.В. Смирнова, издает четыре выдающиеся книги по демографии растений: «Ценопопуляции растений: основные понятия и структура» (1976), «Ценопопуляции растений: развитие и взаимоотношения» (1977), «Динамика ценопопуляций растений» (1985), «Ценопопуляции растений: очерки популяционной биологии» (1988). Их содержание базируются на представлениях о биологическом возрасте растений. В этих монографиях изложен понятийный аппарат и предложена система методов популяционной биологии растений. О.В. Смирнова совместно с Л.Б. Заугольновой, обобщив многолетние исследования проблемной лаборатории и кафедры ботаники МГПИ, разработали представления о характерном онтогенетическом спектре (XОC) и об элементарной демографической единице (ЭДЕ).

ХОС - это полночленный онтогенетический спектр с определенным соотношением численности онтогенетических групп, при котором осуществляется непрерывный оборот поколений. Этот спектр обусловлен биологическими свойствами видов: 1) общей продолжительностью онтогенеза и отдельных возрастных состояний; 2) темпами развития особей в разных онтогенетических состояниях; 3) способами самоподдержания популяции; 4) 
интенсивностью и периодичностью инспермации и элиминации; 5) способностью создавать почвенный запас семян или иных вегетативных зачатков; 6) площадью поглощения ресурсов особями на разных этапах онтогенеза (Заугольнова, 1994; Заугольнова, Смирнова, 1978; Смирнова, 1987; Заугольнова и др., 1992; Восточноевропейские ..., 1994, 2004). Сначала в работах этих исследователей ХОС считался синонимом «базового онтогенетического спектра». Однако в дальнейшем авторы ограничили понятие базового спектра модальным, который получен усреднением данных по нескольким ценопопуляциям, принадлежащих одному варианту сообществ (Смирнова и др., 1993; Заугольнова, 1994).

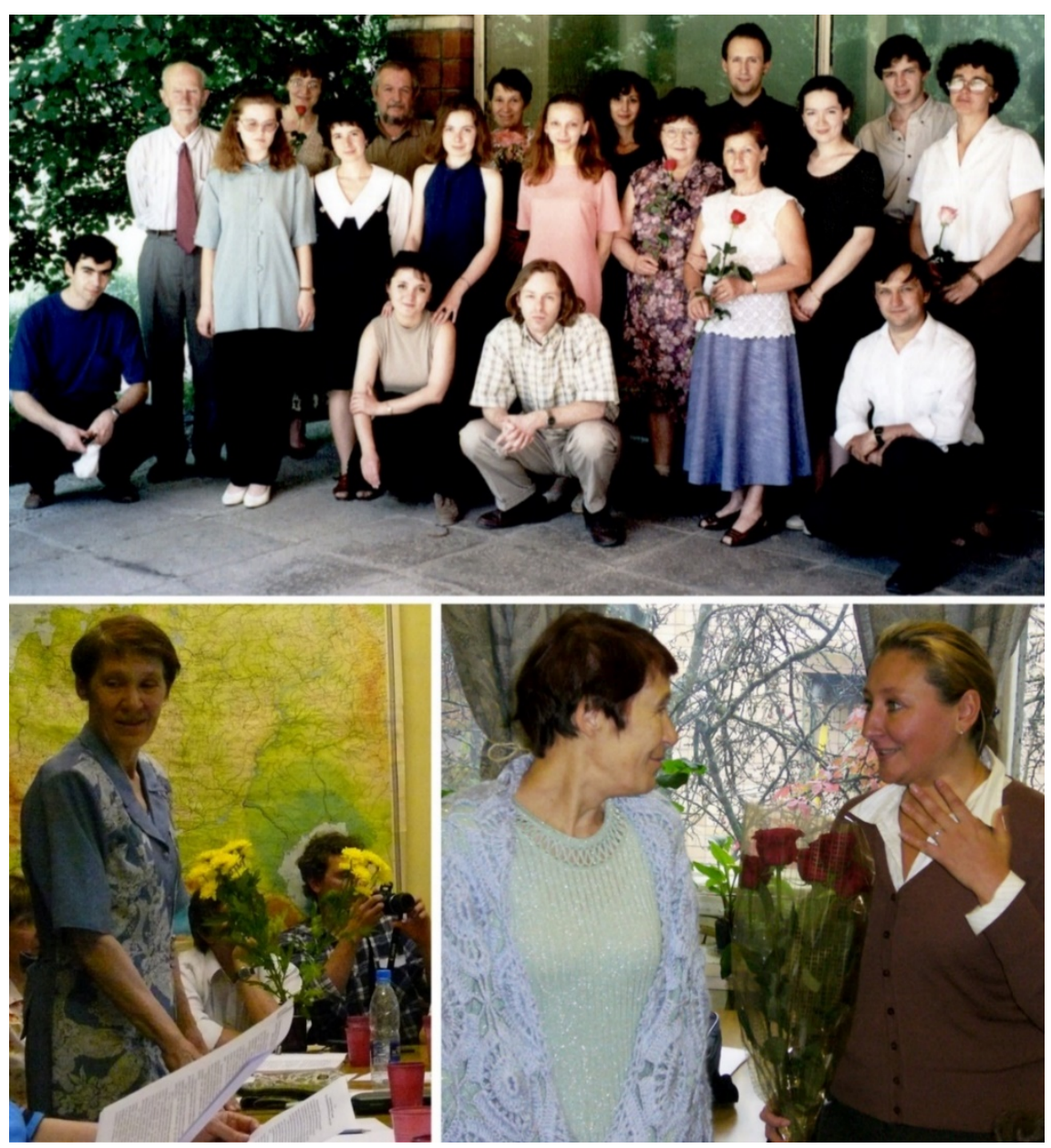

Рисунок 5. Кафедра Системной экологии Учебного центра математической биологии ПущГУ. Вверху. После защиты магистерских работ в июле 1998 года. Сидят слева направо: Рейф Виталий Эдгарович (магистр), Сарычева Елена Петровна (аспирантка), Цыпляновский Андрей Михайлович (аспирант), Быховец Сергей Станиславович (ст. преподаватель). Стоят (первый ряд, слева направо): Синотова Оксана Александровна (магистр), Рубашко Галина Евгеньевна (магистр), Есипова Елена

Сергеевна (магистр), Диденко Елена Геннадьевна (магистр), Медведева Ирина Федоровна (зав. учебной частью), Валентина Сергеевна (лаборант), Турубанова Светлана Афанасьевна (магистр),

Ханина Лариса Геннадьевна (к.б.н., доцент). Стоят (второй ряд, слева направо): Павлов Вадим Николаевич (д.б.н., профессор, председатель ГЭК), Паленова Мария Михайловна (к.б.н., доцент), Комаров Александр Сергеевич (к.б.н., доцент, зав. кафедрой), Смирнова О.В. (д.б.н., профессор), Манукянц Анна Валерьевна (магистр), Тимофеев Владимир Викторович (магистр), Бобровский Максим Викторович (ст. преподаватель). Внизу слева. Выступление О.В. Смирновой на защите магистерских работ 18 июня 2007 года. Внизу справа. Смирнова О.В. и Леонова Наталья Алексеевна

(к.б.н., доцент кафедры ботаники, физиологии и биохимии растений Пензенского университета) после научного семинара 11 октября 1996 года на кафедре Системной экологии 

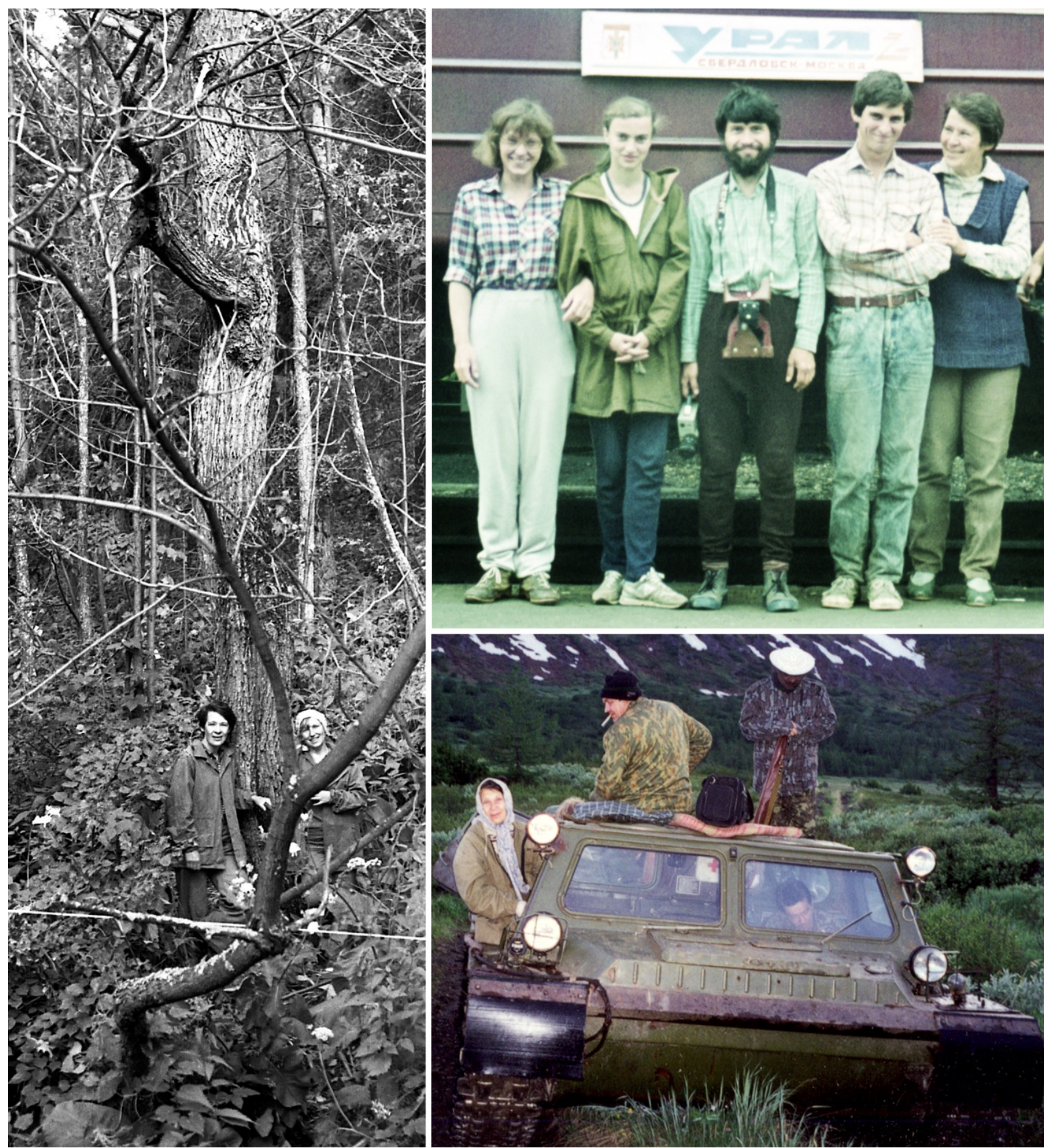

Рисунок 6. Экспедиции (начало). Слева. Смирнова О.В. на пробной площади около вяза шершавого в 1979 году. Сабар, Средний Урал, Артинский район Свердловской области. Фотография О.Г. Баринова. Вверху. Перед поездкой в Сабар в 1991 году. Слева направо: Рипа Светлана Ивановна (аспирантка кафедры ботаники МГПИ), Яницкая Татьяна Олеговна (сотрудник кафедры высших растений МГУ), Баринов Олег Георгиевич (аспирант-химик МГПИ), Коротков Владимир Николаевич (н.с. лаборатории заповедного дела ВНИИ природы), Смирнова О.В. (д.б.н., с.н.с. ПБЛ МГПИ). Фотография М.А Бариновой. Внизу О.В. Смирнова в Горно-Хадытинском заказнике (ЯмалоНенецкий автономный округ) на вездеходе в 1999 году. Фотография М.В. Бобровского 

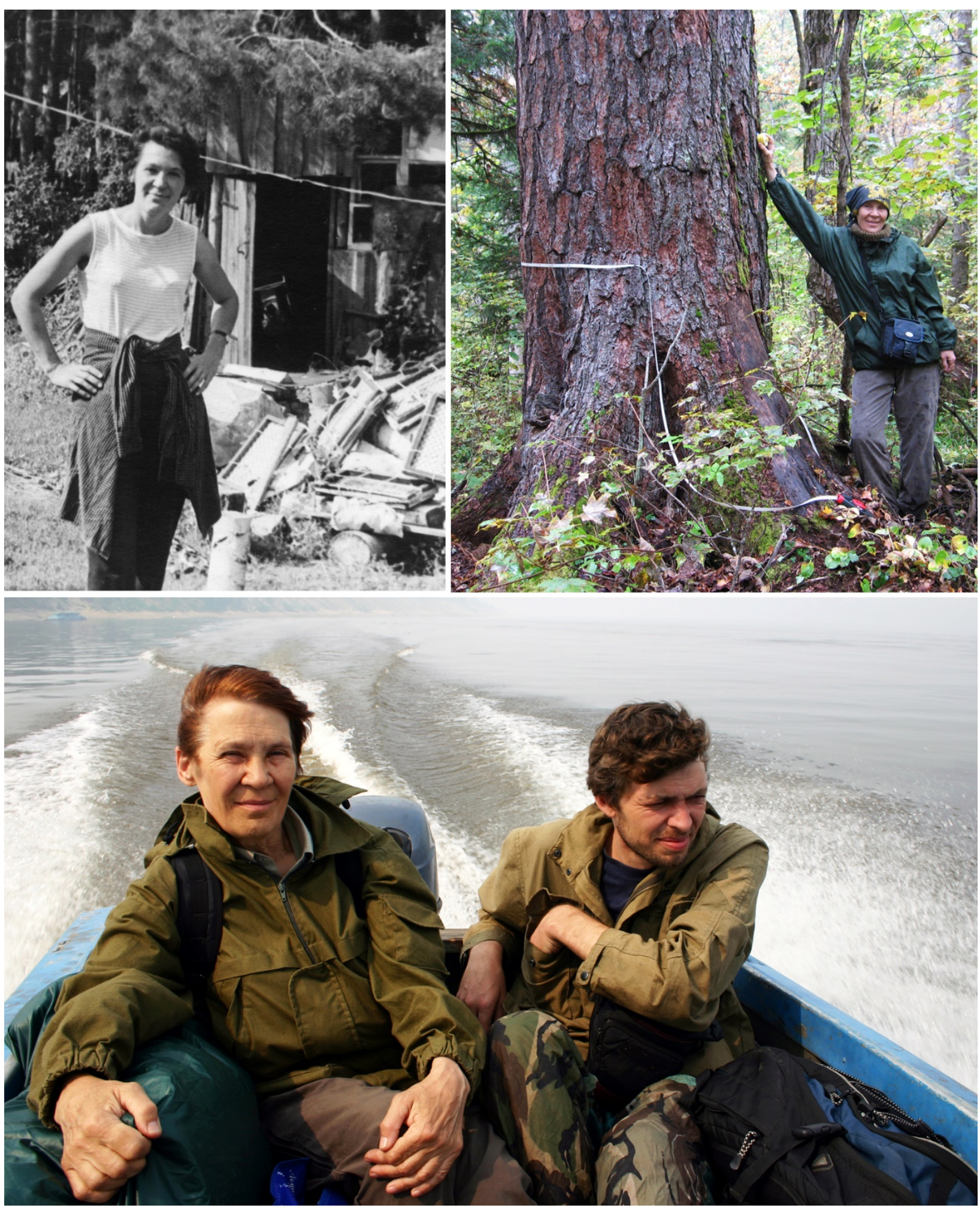

Рисунок 7. Экспедиции (продолжение 1). Вверху слева. О.В. Смирнова в Воронежском заповеднике в 1974 году во время изучения структуры травяного покрова широколиственных лесов. Вверху справа. О.В. Смирнова у кедра корейского в Уссурийском заповеднике (Дальний Восток) в 2008 году. Фотография В.Н. Короткова. Внизу. Обследование долины реки Подкаменная Тунгуска в

июле 2006 года. Эвенкийский район Красноярского края, центральная часть Среднесибирского плоскогорья. Смирнова О.В. и Бобровский Максим Викторович (к.б.н., доцент кафедры Системной экологии ПущГУ). 


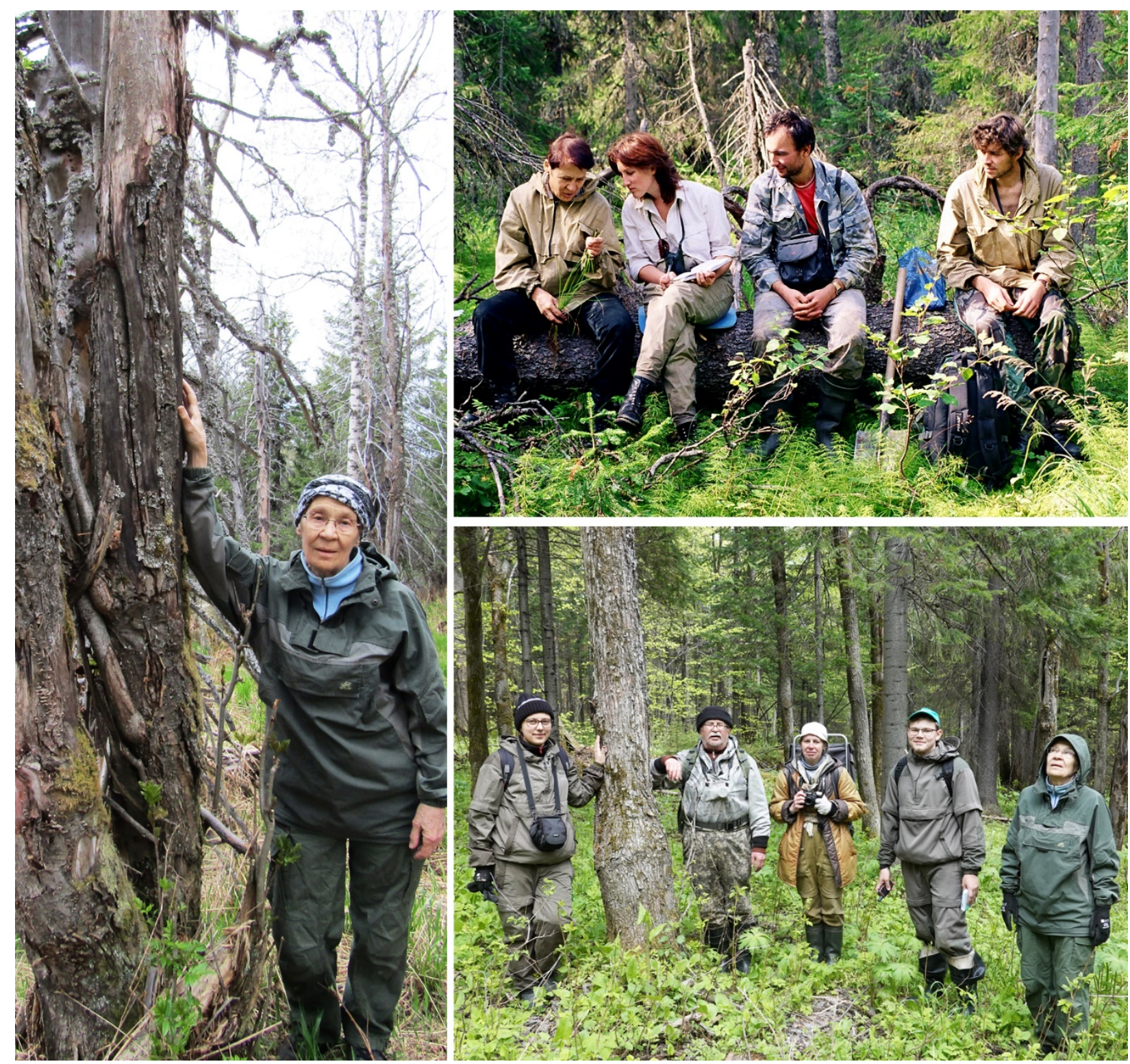

Рисунок 8. Экспедиции (продолжение 2). Слева. О.В. Смирнова в Висимском заповеднике около рябины обыкновенной в мае 2019 года. Фотография А.П. Гераськиной. Вверху. В ПечороИлычском заповеднике в августе 2003 года. Слева направо: О.В. Смирнова, Елена Черненькова сотрудница WWF, Сергей Паутов - сотрудник Омского технологического ун-та, Максим Бобровский

- ст. преподаватель ПущГУ. Фотография В.Н. Короткова. Внизу. В охранной зоне Висимского

заповедника во время обследования уникального хвойно-широколиственного леса с липой сердцевидной и вязом шершавым в мае 2019 года. Слева направо: Гераськина Анна Петровна - к.б.н., зоолог ЦЭПЛ РАН, Сибгатуллин Рустам Зинатович - геоботаник заповедника, Беляева Наталья Вадимовна - фенолог заповедника, Шилов Денис Сергеевич - флорист заповедника, Смирнова О.В. Фотография В.Н. Короткова.

ХОС отражает динамически устойчивое (дефинитивное) состояние цепопуляции, к которому она возвращается после отклонений, вызванных влиянием внешних воздействий. Реальный онтогенетический спектр в наибольшей степени совпадает с характерным в ненарушенных (климаксных) сообществах. В ценозах, преобразованных человеком, онтогенетический спектр популяции, как правило, в разной степени отклонен от характерного 
(Ценопопуляции ..., 1976; Смирнова и др., 1987, 1989, 1990, 1991, 1992; Восточноевропейские ..., 1994).

О.В. Смирнова показала, что у растений существуют три типа характерных спектров (Смирнова, 1987; Восточноевропейские ..., 1994). Первый тип - левосторонний, максимум приходится на прегенеративные особи. Отмечен у деревьев, моно- и олигокарпических стержнекорневых трав, луковичных, клубнелуковичных и клубневых геофитов. Эти растения активно размножаются семенным путем и/или глубоко омоложенными вегетативными зачатками. Второй тип - центрированный спектр, наибольшее число особей располагается на средневозрастных генеративных растениях. Характерен для стержнекорневых, длинно- и короткокорневищных трав, дерновинных злаков и полукустарничков. У них слабо выражен период старения, размножение семенное или смешанное, вегетативное размножение не сопровождается глубоким омоложением. Третий тип - бимодальный спектр с двумя максимумами: один - в молодой части, а другой - на зрелых или старых генеративных особях. Описан у плотно- и рыхлодерновинных злаков, стержнекорневых и короткокорневищных трав, у полукустарничков. Растения отличаются значительной продолжительностью жизни с хорошо выраженным периодом старения, активное семенное размножение сочетается с вегетативным без глубокого омоложения.

ЭДЕ - популяционная единица, представляющая собой множество разновозрастных особей одного вида, которое необходимо и достаточно для обеспечения устойчивого оборота поколений на минимально возможной площади. Важные характеристики ЭДЕ: 1) минимальная численность, при которой может осуществляться непрерывный оборот поколений; 2) минимальное пространство, необходимое для устойчивого потока поколений; 3) время жизни одного поколения (Смирнова и др., 1989; Заугольнова и др., 1993). ЭДЕ разных видов по значениям каждого из перечисленных признаков располагаются в континуальные ряды (табл. 2).

Таблица 2. Некоторые параметры элементарных демографических единиц (ЭДЕ) растений широколиственных лесов (Смирнова и др., 1992)

\begin{tabular}{|l|c|c|}
\hline \multicolumn{1}{|c|}{ Вид } & $\begin{array}{c}\text { Время жизни одного } \\
\text { поколения, годы }\end{array}$ & $\begin{array}{c}\text { Минимальное } \\
\text { пространство, } \text { M }^{2}\end{array}$ \\
\hline Quercus robur L. & 350 & $4.20 \times 10^{5}$ \\
\hline Fraxinus excelsior L. & 250 & $1.30 \times 10^{5}$ \\
\hline Tilia cordata Mill. & 180 & $2.70 \times 10^{4}$ \\
\hline Acer platanoides L. & 180 & $1.80 \times 10^{4}$ \\
\hline Carpinus betulus L. & 120 & $1.20 \times 10^{4}$ \\
\hline Corylus avellana L. & 80 & $2.50 \times 10^{3}$ \\
\hline Lathyrus vernus (L.) Bernh. & 20 & $1.00 \times 10^{0}$ \\
\hline Corydalis bulbosa (L.) DC. & 10 & $0.25 \times 10^{0}$ \\
\hline Geranium robertianum L. & 1 & $1.00 \times 10^{0}$ \\
\hline
\end{tabular}


Представление об ЭДЕ позволило О.В. Смирновой дать более глубокое определение важному понятию лесной экологии - эдификатору (Смирнова, 1998; Смирнова, Торопова, 2008). К этой категории относятся виды с наиболее крупными ЭДЕ и длительно существующими популяционными мозаиками. Они включают в циклы оборота поколений наибольшую порцию вещества и энергии. Эдификаторы принадлежат к мощными средопреобразователям. Популяции эдификаторов при спонтанном развитии в наибольшей степени преобразуют местообитание: изменяют гидрологический, температурный и световой режим сообщества, создают микро- и мезорельеф, трансформируют почвенный покров. Внутренняя гетерогенность местообитания ЭДЕ вида-эдификатора позволяет существовать вместе экологически и биологически различным видам с меньшими размерами ЭДЕ, а также поддерживает высокий уровень биоразнообразия. Синонимы понятия «эдификатор» «ключевой вид» (keystone species) и «экосистемный инженер» (ecosystem engineer). В лесной зоне к эдификатором относят виды разных трофических групп и разного систематического положения: например, крупные деревья, хвое- и листогрызущие насекомые, дереворазрушающие грибы, в пойменных сообществах к ним присоединяется бобр речной.

\section{Концепция популяционной организации биогеоценозов}

О.В. Смирнова активно разрабатывает представление о структуре и динамике ненарушенных (климаксных) лесных биогеоценозов, которые существовали в доагрикультурное время без вмешательства человека (Восточноевропейские ..., 1994, 2004; Смирнова и др., 1988, 1989, 1990; Смирнова, 1998, 2000; Смирнова, Торопова, 2008). В основе этого понимания лежит популяционный взгляд на сообщество и биогеоценотический покров. Согласно концепции популяционной организации биогеоценозов, лесной покров следует рассматривать как иерархию популяционных единиц видов разных трофических групп. Популяционная жизнь эдификаторов объединяет эту разномасштабную мозаику в сообщества. Популяционные мозаики ключевых видов создают условия для устойчивого существования популяций множества подчиненных видов и определяют максимальное видовое разнообразие сообществ.

Фитогенная мозаичность в ненарушенных лесах - результат популяционной жизни деревьев-эдификаторов. В лесах популяционная жизнь деревьев создает мозаику светового, водного и почвенного режимов. Эта мозаика - результат образования прорывов в пологе леса вследствие старения и смерти одного или нескольких рядом растущих деревьев. Смерть дерева и связанная с ним пертурбация почвы определяют формирование ветровальнопочвенных комплексов. При этом создается специфический вывальный микрорельеф, включающий бугры, западины и валежник (Бобровский, 2004, 2013). Неоднородность среды в 
виде окон и ветровально-почвенных комплексов, созданная в результате потоков поколений в популяциях деревьев-эдификаторов, обуславливает присутствие в ненарушенных лесах максимально возможного набора подчиненных видов растений, животных, грибов и представителей других царств. В результате изучения этой мозаичности О.В. Смирнова и ее ученики создали новую систему представлений в лесной экологии - геп-парадигму (Коротков, 1991, 1993; Смирнова, 1998; Оценка ..., 2000).

O.В. Смирнова убедительно показывает, что мозаичность, вызванная жизнедеятельностью животных-фитофагов, столь же характерное свойство лесных ландшафтов, как и фитогенная (Смирнова и др., 1993; Восточноевропейские ..., 1994, 2004). Зоогенная мозаичность в доагрикультурных лесах - результат популяционной жизни животных-эдификаторов. В ненарушенных европейских лесах к этим животным относились: 1) крупные стадные копытные (зубры, туры, тарпаны и др.); 2) листо- и хвоегрызущие насекомые; 3) бобры. Крупные стадные копытные, которые уничтожали молодые деревья, кустарники и травы, а также уплотняли и унаваживали почву, создавали зоогенные поляны с лугово-опушечной и лугово-степной флорой. Насекомые, уничтожая листья и хвою деревьев, увеличивают освещенность на поверхности травяного покрова, повышают температуру воздуха и почвы, обогащают почву азотом и другими минеральными веществами, а также способствуют возрастанию численности светолюбивых и нитрофильных видов трав. Бобры, возводя плотины на ручьях и мелких речках, создают пруды и низинные болота, увеличивают видовое разнообразие и численность сопутствующих видов растений и животных. Бобры, уничтожая деревья и кустарники в прибрежной полосе, формируют поляны со светолюбивой флорой и фауной.

О.В. Смирнова показывает, что сильные антропогенные воздействия, разрушая популяционную мозаику, разрывают циклы оборотов поколений ключевых видов. В результате до восстановления естественной мозаики развитие сообществ становится однонаправленным - сукцессионным. Представления о популяционной организации биогеоценозов и количественная оценка популяционных параметров основных ценозообразователей дает возможность реконструировать потенциальную структуру биогеоценотического покрова территорий, количественно оценить степень нарушенности сообществ и их комплексов, а также упорядочить существующие сукцессионные системы.

\section{Концепция антропогенной трансформации лесного покрова в голоцене}

Несмотря на большое число работ, посвященных антропогенной трансформации биогеоценотического покрова в голоцене, в отечественной науке все еще господствует миграционно-климатическая парадигма. О.В. Смирнова, обобщив исторические и 
палеонтологические данные, предлагает новую «антропическую» систему взглядов, согласно которой человек - основной фактор преобразования биогеоценотического покрова в голоцене (Смирнова, Бобровский, 2000; Смирнова и др., 2001a, 2001б, 2006, 2013; Турубанова, 2002; Смирнова, Турубанова, 2003; Харитоненков, 2012; Смирнова, Торопова, 2016; Kalyakin et al., 2016; Smirnova, Toropova, 2016; Smirnova et al., 2018). Суть новой парадигмы в следующем.

Письменные источники свидетельствуют, что за последние 1-2 тысячелетия разнообразие жизни на Земле стремительно сокращается в связи с антропогенными преобразованиями. Однако палеонтологические исследования говорят о том, что время значительных преобразований на Русской равнине и всей Северной Евразии на порядок больше. Первый экологический кризис, обусловленный человеком, на этой территории случился 22-18 тысяч лет назад. Он был вызван истреблением основных эдификаторов позднего плейстоцена - мамонтов, шерстистого носорога, гигантского оленя и других. Эти животные определяли состав и структуру растительного покрова и животного мира того времени. Основа их питания - травы, в первую очередь злаки, растущие на лугово-степных полянах и опушках. Лугово-степные сообщества чередовались с небольшими скоплениями деревьев. При этом, как свидетельствует палинология, в плейстоцене на всей Русской равнине произрастали и хвойные, и широколиственные виды деревьев. Почвы криогенных саван, под которыми был слой вечной мерзлоты, по химическим свойствам подобны современным черноземам. Продуктивность их на всей территории Северной Евразии была так велика, что позволяла устойчиво существовать огромным стадам гигантов-фитофагов и их свите. Эта особенность получила у палеозоологов название «парадокс доисторических пастбищ». Именно в криогенных саванах конца плейстоцена (поздний или финальный палеолит) найдены стоянки охотников на мамонтов с высоким уровнем хозяйства и культуры.

В течение последних 10000-7000 лет отмечено общее потепление климата, что совпало с постепенным истреблением ключевых видов - гигантов и крупных животных мамонтового комплекса в результате охоты. Деградация мамонтового комплекса, начавшаяся еще в позднем плейстоцене, привела к усилению роли древесной растительности. Пастбища, на которых паслись мамонты и их спутники, заселялись деревьями. Первыми внедрялись деревья с легколетучими семенами и быстрым оборотом поколений: береза, ива, осина, сосна обыкновенная. Затем - темнохвойные (ель, пихта) и широколиственные (дуб, липа, клен, ясень, бук, граб и др.) деревья. Почти полное исчезновение гигантов и самых крупных фитофагов мамонтового комплекса, в сочетании с потеплением, положили начало формированию лесного пояса в раннем голоцене на месте криогенных саван плейстоцена.

В начале среднего голоцена (7000-2500 лет назад) на Русской равнине практически полностью образовался лесной пояс с доминированием широколиственных и темнохвойных 
видов деревьев; он занимал пространство от северных до южных морей. В пределах лесного пояса вследствие средопреобразующей деятельности зубров, туров, тарпанов, сайги и других животных постоянно создавались зоогенные поляны с луговыми и степными растениями. На небольших водотоках формировались поселения бобров с водно-болотными угодьями. В результате биогеоценотический покров среднего голоцена представлял собой множество лесолугово-болотных комплексов, которые создавались и регулировались ключевыми видами: крупными стадными копытными, бобрами и деревьями.

C середины среднего голоцена оформляется мощнейший фактор воздействия на биогеоценотический покров - хозяйство производящего типа (земледелие, скотоводство, выплавка металлов). В остеологическом материале этого времени сильно сократилась доля костей диких копытных (зубра, тура, тарпана и др.) и возросло участие костей домашнего скота, а в спорово-пыльцевых спектрах появилась пыльца культурных злаков. Производящее хозяйство принципиально изменило структуру биогеоценотического покрова. В первую очередь исчезают крупные стадные копытные и бобры не только в результате охоты, но и вследствие коренного преобразования необходимых для их жизни местообитаний под воздействием подсечно-огневого земледелия, рубок леса и других промыслов. По мере уничтожения ключевых видов животных участие природных лугово-степных экосистем сокращалась, а лесных - возрастала. В результате существование светолюбивых видов деревьев (прежде всего дуба и сосны), а также всех светолюбивых видов растений других жизненных форм, и многих видов животных, ранее обитавших на зоогенных полянах, стало возможным только в антропогенных местообитаниях. Например, пионерные деревья возобновлялись в основном на заброшенных пашнях.

Относительно «независимыми» от человека остались экосистемы «теневых» хвойношироколиственных лесов, их спонтанное развитие возможно и сейчас при заповедном режиме. Однако в этих сообществах может устойчиво существовать лишь часть природной флоры и фауны региона. В современном лесном покрове Русской равнины экосистемы в виде «осколков» среднеголоценовых лесо-лугово-болотных комплексов сохранились только в небольшом числе рефугиумов, незатронутых сильными антропогенными преобразованиями последних столетий.

Именно с конца среднего голоцена становится принципиально невозможным восстановление потенциального (былого) биогеоценотического покрова в спонтанном режиме, поскольку, с одной стороны, численность популяций ключевых видов животных (крупных стадных копытных и бобров) сильно сократилась, а с другой - наиболее мощным средопреобразователем стал человек. Его деятельность начала определять существование тех или иных подчиненных видов растений и животных. 
К концу среднего голоцена выжигание лесов в цикле подсечно-огневого земледелия существенно отодвинуло на север южную границу лесного пояса. Распространение кочевого скотоводства на юге Русской равнины вело к формированию степной и полупустынно-степной зон. Эти события были крупным шагом к формированию современной зональности и, вероятно, оказали существенное влияние и на изменения макроклимата Евразии в целом. Возможно, они явились одной из причин нарастания нестабильности климата второй половины голоцена.

В период от железного века до раннего Средневековья (2500-500 лет назад), главным образом в результате подсечно-огневого земледелия, существенно отступили на юг северные границы ареалов видов широколиственных деревьев, что положило начало формированию современной тайги - лесной полосы, где нет этих видов. Одновременно на песчаных почвах лесного пояса были сформированы специфические пирогенные леса с господством сосны обыкновенной. Подсечно-огневое, а затем переложное и пахотное земледелие, выпас в лесу, сбор подстилки и валежника и прочее лесопользование привели к деградации почвенного покрова на больших площадях. Выжигание лесов на их северной границе было причиной развития в позднем голоцене зоны тундр из лесотундры и северной тайги.

В целом производящее хозяйство среднего и позднего голоцена разделило единый лесо-лугово-болотный комплекс на две группы: 1) экосистемы, способные поддерживать себя при спонтанном развитии («теневые» леса), сформировавшие собственно лесной пояс; 2) экосистемы, требующие для своего поддержания постоянного антропогенного воздействия (пойменные и суходольные луга, луговые степи, леса из пионерных видов деревьев). Одновременно был сделан завершающий шаг при формировании антропогенной зональности - под влиянием деятельности человека единый лесной пояс Русской равнины распался на хвойные, хвойно-широколиственные и широколиственные леса.

\section{ЗАКЛЮЧЕНИЕ}

Система взглядов О.В. Смирновой построена на представлениях о ведущей роли популяций растений и животных в организации биогеоценотического покрова. При этом подразумевается, что непрерывный оборот поколений в популяциях эдификаторов (ключевых видов) - необходимое условие для поддержания видового и структурного разнообразия сообществ, а также для обеспечения их устойчивости. Эта система взглядов сформировалась под влиянием идей профессора А.А. Уранова. Развитие популяционных представлений было последовательным и постепенным. Сначала О.В Смирнова изучает биологию видов растений разных жизненных форм, их индивидуальное развитие, в котором выделяет онтогенетические состояния, необходимые для демографических исследований, затем - разрабатывает теорию 
ценопопуляций как надорганизменных систем, способных к самоподдержанию в различных условиях, и, наконец, - развивает учение о популяционной организации биогеоценозов и создает концепцию антропогенной трансформации лесного покрова в голоцене. Все это помогает понять механизмы формирования современной зональности, которые обусловлены деятельностью человека.

Поздравляем Ольгу Всеволодовну с юбилеем, желаем ей долгих лет жизни, новых творческих успехов, бодрости и здоровья! К поздравлению авторов присоединяются коллеги и ученики, а также редколлегия журнала «Вопросы лесной науки».

\section{БЛАГОДАРНОСТИ}

Авторы благодарят за помощь в подготовке статьи Баринова Олега Георгиевича, Баринову Марию Альбертовну, Бобровского Максима Викторовича, Богомолову Наталью Николаевну, Горнова Алексея Владимировича, Есипову Елену Сергеевну, Железную Екатерину Львовну, Кобозеву Екатерину Александровну, Рипу Светлану Ивановну, Романова Михаила Сергеевича, Романовского Андрея Михайловича, Сарычеву Елену Петровну, Смирнова Николая Сергеевича и Ханину Ларису Геннадьевну.

\section{ЛИТЕРАТУРА}

Алейников А.А. Состояние популяции и средопреобразующая деятельность бобра европейского на территории заповедника «Брянский лес» и его охранной зоны: автореф. дис. ... канд. биол. наук (спец. 03.02.08). Тольятти: Ин-т экологии Волжского бассейна РАН, 2010. $22 \mathrm{c}$.

Аргунова М.В. Популяционная организация дубово-грабовых лесов Западной Украины и оптимизация их структуры: автореф. дис. ... канд. биол. наук (спец. 03.02.08). М.: МГПУ им. В.И. Ленина, 1993. 16 с.

Аргунова М.В. Экологическое образование в интересах устойчивого развития как надпредметное направление модернизации школьного образования: автореф. дис. ... д-ра. пед. наук (спец. 13.00.02). М.: Моск. гос. обл. ун-т, 2010. 47 с.

Баринова М.А. Влияние водохранилища на синузии зеленых мхов долины Гилюя: автореф. дис. ... канд. биол. наук (спец. 03.02.08). М.: МГПУ им. В.И. Ленина, 1997. 16 с.

Бобровская Н.Е. Формирование структуры крон лиственных и хвойных деревьев в онтогенезе: автореф. дис. ... канд. биол. наук (спец. 03.02.08). М.: МГПУ, 2001. 19 с.

Бобровский М.В. Биотические и антропогенные факторы долговременной динамики лесных почв Европейской России: автореф. дис. ... д-ра биол. наук (спец. 03.02.08). Владимир: им. А.Г. и Н.Г. Столетовых, 2013. 48 с. 
Бобровский M.B. Разнообразие растительности и почв заповедника «Калужские засеки» и его связь с традиционным природопользованием: автореф. дис. ... канд. биол. наук (спец. 03.02.08). М.: МГПУ, 2004. 23 с.

Богданова Н.Г. Формирование травяного покрова хвойно-широколиственных и широколиственных лесов в ходе восстановительных сукцессий в Неруссо-Деснянском полесье: автореф. дис. ... канд. биол. наук (спец. 03.02.08). М.: МГПУ, 2006. 21 с.

Браславская Т.Ю. Биологическое разнообразие и динамика растительности в пойме малой реки Южного Нечерноземья (на примере р. Нерусса, Брянская обл.): автореф. дис. ... канд. биол. наук (спец. 03.02.08). М.: МГПУ, 2001. 21 с.

Возрастной состав популяций цветковых растений в связи с их онтогенезом. Уранов А.А. (ред.). М.: МГПИ им. В.И. Ленина, 1974. 216 с.

Вопросы морфогенеза цветковых растений и строения их популяций. Уранов А.А. (ред.). М.: Наука, 1968. 234 с.

Восточноевропейские леса: история в голоцене и современность. Смирнова О.В. (ред.). М.: Наука, 2004a. Кн. 1.479 с.

Восточноевропейские леса: история в голоцене и современность. Смирнова О.В. (ред.). М.: Наука, 2004б. Кн. 2. 575 с.

Восточноевропейские широколиственные леса. Смирнова О.В. (ред.). М.: Наука, 1994. $364 \mathrm{c}$.

Динамика ценопопуляций растений. Серебрякова Т.И. (ред.). М.: Наука, 1985. 208 с.

Евстигнеев О.И. Механизмы поддержания биологического разнообразия лесных биогеоценозов: автореф. дис. ... д-ра биол. наук (спец. 03.02.08). Нижний Новгород: ННГУ им. Н.И. Лобачевского, 2010. 48 с.

Евстигнеев О.И. Популяционные стратегии видов деревьев // Восточноевропейские леса: история в голоцене и современность. М.: Наука, 2004. Кн. 1. С. 176-205.

Евстигнеев О.И. Фитоценотипы и отношение лиственных деревьев к свету: автореф. дис. ... канд. биол. наук (спец. 03.02.01). М.: МГПИ им. В.И. Ленина, 1990. 17 с.

Евстигнеев О.И., Диденко Е.Г. Популяционные стратегии видов кустарников // Восточноевропейские леса: история в голоцене и современность. М.: Наука, 2004. Кн. 2. С. 205-224.

Жукова Л.А. Мир принадлежит оптимистам // Поливариантность развития организмов, популяций и сообществ. Йошкар-Ола: Мар. гос. ун-т, 2006. С. 229-278.

Запрудина М.В. Микромозаичная организация травяно-кустарничкового и мохового покрова среднетаежных темнохвойных лесов Урала: автореф. дис. ... канд. биол. наук (спец. 03.02.08). М.: МГПУ, М., 2012. 23 с. 
Заугольнова Л.А., Жукова Л.А., Попадюк Р.В., Смирнова О.В. Критическое состояние ценопопуляций растений // Проблемы устойчивости биологических систем. М.: Наука, 1992. C. 51-59.

Заугольнова Л.Б., Смирнова О.В. Возрастная структура ценопопуляций многолетних растений и ее динамика // Журн. общ. биол. 1978. Т. 39. № 6. С. 849-858.

Заугольнова Л.Б. Связь возрастного спектра ценопопуляций с биологическими свойствами вида // Возрастной состав популяций цветковых растений в связи с их онтогенезом. М.: МГПИ им. В.И. Ленина, 1974. С. 38-55.

Заугольнова Л.Б. Структура ценопопуляций семенных растений и проблемы их мониторинга: дис. ... д-ра биол. наук (спец. 03.02.01). СПб: СПб гос. ун-т, 1994. 70 с.

Заугольнова Л.Б., Смирнова О.В., Комаров А.С., Ханина Л.Г. Мониторинг фитопопуляций // Успехи соврем. биол. 1993. Т. 113. № 4. С. 402-414.

Истомина И.И. Квазисенильность и ее роль в жизни древесных растений: автореф. дис. ... канд. биол. наук (спец. 03.02.01). М.: МГПУ им. В.И. Ленина, 1993. 16 с.

Киселева Л.Л. Эколого-флористический анализ экотонных сообществ центральной лесостепи: автореф. дис. ... канд. биол. наук (спец. 03.02.01). М.: МГПУ им. В.И. Ленина, 1994. $16 \mathrm{c}$.

Коротков В.Н. Демутационные процессы в островных лесных массивах (на примере ГИЗЛ «Горки Ленинские» и Каневского заповедника): автореф. дис. ... канд. биол. наук (спец. 03.02.08). М.: МГПУ им. В.И. Ленина, 1993. 16 с.

Коротков В.Н. Новая парадигма в лесной экологии // Биологические науки. 1991. № 8. C. 7-20.

Луговая Д.Л. Роль экотопических и антропогенных факторов в формировании видового и структурного разнообразия южнотаежных лесов (восток Костромской области): автореф. дис. ... канд. биол. наук (спец. 03.02.08). М.: МГПУ, 2008. 28 с.

Недосеко О.И. Онтоморфогенез Salix pentandra L., Salix caprea L., Salix cinerea L.: автореф. дис. ... канд. биол. наук (спец. 03.02.01). М.: МГПУ им. В.И. Ленина, 1993. 16 с.

Недосеко О.И. Становление жизненных форм и архитектоники крон бореальных видов ив подродов Salix и Vetrix Dumort. в онтогенезе: автореф. дис. ... д-ра биол. наук (спец. 03.02.01). М.: МСХА им. К.А. Тимирязева, 2018. 43 с.

Онтогенез и возрастной состав популяций цветковых растений. Уранов А.А. (ред.). М.: Наука, 1967. 156 с.

Оценка и сохранения биоразнообразия лесного покрова в заповедниках Европейской России. М.: Научный мир, 2000. 196 с. 
Попов С.Ю. Структура и динамика растительности Керженского заповедника: автореф. дис. ... канд. биол. наук (спец. 03.02.08). М.: МГПУ, 2008. 20 с.

Работнов Т.А. Жизненный цикл многолетних травянистых растений в луговых ценозах // Труды БИН АНСССР. Сер. 3. Геоботаника. 1950. Вып. 6. С. 7-204.

Раменский Л.Г. О принципиальных установках, основных понятиях и терминах производственной типологии земель, геоботаники и экологии // Советская ботаника. 1935. № 4. C. 25-41.

Puna С.И. Популяционно-ценотический анализ горных буковых и смешанных лесов Украинских Карпат: автореф. дис. ... канд. биол. наук (спец. 03.02.08). М.: МГПУ им. В.И. Ленина, 1997. 16 с.

Романовский A.M. Особенности онтогенеза и фитоценотичеекая роль ели европейской в лесах Неруссо-Деснянского полесья: автореф. дис. ... канд. биол. наук (спец. 03.02.08). М.: МГПУ, 2006. $18 \mathrm{c}$.

Самохина Т.Ю. Структура и спонтанная динамика хвойно-широколиственных лесов Среднего Урала: автореф. дис. ... канд. биол. наук (спец. 03.02.08). М.: МГПУ им. В.И. Ленина, 1997. $16 \mathrm{c}$.

Сарычева Е.П. Структурное и видовое разнообразие черноольховых лесов центра европейской России (на примере заповедников “Брянский лес” и “Воронинский”): автореф. дис. ... канд. биол. наук (спец. 03.02.08). М.: МГПУ, 2000. 16 с.

Смирнова О.В. Жизненные циклы, численность и возрастной состав популяций основных компонентов травяного покрова дубрав: дис. ... канд. биол. наук (спец. 03.02.01). М.: МГПИ им. В.И. Ленина, 1968. 285 с.

Смирнова O.B. Поведение видов и функциональная организация травяного покрова широколиственных лесов (на примере равнинных широколиственных лесов Европейской части СССР и липняков Сибири): дис. ... д-ра биол. наук (спец. 03.02.01). Л.: ЛГУ им. А.А. Жданова, 1983. 685 с.

Смирнова O.B. Поведение видов и функциональная организация травяного покрова широколиственных лесов Европейской части СССР // Бюл. МОИП. Отд. биол. 1980. Т. 85. Вып. 5. С. 53-67.

Смирнова O.B. Популяционная организация биогеоценотического покрова лесных территорий // Оценка и сохранения биоразнообразия лесного покрова в заповедниках Европейской России. М.: Научный мир, 2000. С. 14-22.

Смирнова O.B. Популяционная организация биоценотического покрова лесных ландшафтов // Успехи соврем. биол. 1998. Т. 118. № 2. С. 148-165. 
Смирнова O.B. Структура травяного покрова широколиственных лесов. М.: Наука, 1987. $208 \mathrm{c}$.

Смирнова О.В., Бакун Е.Ю., Турубанова С.А. Представление о потенциальном и восстановленном растительном покрове лесного пояса Восточной Европы // Лесоведение. 2006. № 1. C. 22-33.

Смирнова О.В., Бобровский М.В. Воздействие производящего хозяйства на состав и структуру лесного покрова // Оценка и сохранения биоразнообразия лесного покрова в заповедниках Европейской России. М.: Научный мир, 2000. С. 22-26.

Смирнова О.В., Возняк Р.Р., Евстигнеев О.И., Коротков В.Н., Носач Н.Я., Попадюк P.B., Самойленко B.К., Торопова Н.А. Популяционная диагностика и прогнозы развития заповедных лесных массивов (на примере Каневского заповедника) // Бот. журн. 1991. Т. 76. № 6. C. $860-871$.

Смирнова О.В., Заугольнова Л.А., Попадюк Р.В. Популяционная концепция в биоценологии // Журн. общ. биол. 1993. Т. 54. № 4. С. 438-448.

Смирнова О.В., Калякин В.Н., Турубанова С.А., Бобровский М.В. Современная зональность Восточной Европы как результат преобразования позднеплейстоценового комплекса ключевых видов // Мамонт и его окружение: 200 лет изучения. М.: Геос, 2001а. С. 200-208.

Смирнова О.В., Луговая Д.Л., Проказина Т.С. Модельная реконструкция восстановленного лесного покрова таежных лесов // Успехи соврем. биол. 2013. Т. 133. №. 2. C. $164-177$.

Смирнова О.В., Попадюк Р.В., Чистякова А.А. Популяционные методы определения минимальной площади лесного ценоза // Бот. журн. 1988. Т. 73. № 10. С. 1423-1433.

Смирнова О.В., Попадюк Р.В., Янищкая Т.О., Коротков В.Н. Пути восстановления популяционной структуры и видового разнообразия в лесных демутационных комплексах // Биологические науки. 1992. №5. С. 7-25.

Смирнова O.B., Торопова Н.A. Потенциальная растительность и потенциальный экосистемный покров // Успехи соврем. биол. 2016. Т. 136. № 2. С. 199-211.

Смирнова O.B., Торопова Н.A. Сукцессия и климакс как экосистемный процесс // Успехи соврем. биол. 2008. Т. 128. № 2. С. 129-144.

Смирнова O.В., Турубанова С.A. Формирование и развитие Восточноевропейских широколиственных лесов в голоцене // Бюл. МОИП. Отд. биол. 2003. Т. 108. Вып. 2. С. 32-40.

Смирнова О.В., Турубанова С.А., Бобровский М.В., Коротков В.Н., Ханина Л.Г. Реконструкция истории биоценотического покрова Восточной Европы и проблема поддержания биологического разнообразия // Успехи соврем. биол. 2001б. № 2. С. 144-159. 
Смирнова O.B., Чистякова A.A. Анализ фитоценотических потенций некоторых древесных видов широколиственных лесов Европейской части СССР // Журн. общ. биол. 1980. T. 41. № 3. C. 350-362.

Смирнова О.В., Чистякова А.А., Дробышева Т.И. Ценопопуляционный анализ и прогнозы развития дубово-грабовых лесов Украины // Журн. общ. биол. 1987. Т. 48. № 2. С. 200-212.

Смирнова О.В., Чистякова А.А., Попадюк Р.В. Популяционные механизмы динамики лесных ценозов // Биологические науки. 1989. № 11. С. 48-58.

Смирнова О.В., Чистякова А.А., Попадюк Р.В., Евстигнеев О.И., Коротков В.Н., Митрофанова M.В., Пономаренко E.B. Популяционная организация растительного покрова лесных территорий (на примере широколиственных лесов европейской части СССР). Пущино: ОНТИ Научный центр биол. исследований АН СССР, 1990. 92 с.

Смирнова О.В., Чистякова А.А., Рипа С.И., Лысых Н.И. Популяционная организация буковых лесов Закарпатья // Бюл. МОИП. Отд. биол. 1989. Т. 94. Вып. 5. С. 78-91.

Смирнова Ольга Всеволодовна // Интеллектуальная Система Тематического Исследования Наукометрических данных. URL: http://istina.msu.ru/profile/sov1933/.

Сугоркина Н.С. Онтогенез и особенности популяционной биологии видов рода герань: автореф. дис. ... канд. биол. наук (спец. 03.02.01). М.: МГПИ им. В.И. Ленина, 1989. 17 с.

Турубанова С.А. Экологический сценарий истории формирования живого покрова Европейской России и сопредельных территорий на основе реконструкции ареалов ключевых видов животных и растений: автореф. дис. ... канд. биол. наук (спец. 03.02.08). М.: Ин-т биол. Коми научн. центра Уральского отд. РАН, 2002. 23 с.

Харитоненков М.A. Роль антропогенного фактора в формировании растительного покрова юга Западно-Сибирской равнины в эпоху традиционного природопользования (с позднего палеолита до конца XIX в.): автореф. дис. ... канд. биол. наук (спец. 03.02.08). М.: Моск. гос. обл. ун-т, 2012. 25 с.

Ценопопуляции растений (основные понятия и структура). Уранов А.А., Серебрякова Т.И. (ред.). М.: Наука, 1976. 217 с.

Ценопопуляции растений (очерки популяционной биологии). М.: Наука, 1988. 184 с.

Ценопопуляции растений (развитие и взаимоотношения). Серебрякова Т.И. (ред.). М.: Наука, 1977. 135 с.

Чумаченко С.И. Биоэкологическая модель разновозрастного лесного ценоза: автореф. дис. ... канд. биол. наук (спец. 03.02.08). М.: МГПУ им. В.И. Ленина, 1993. 16 с. 
Чумаченко С.И. Имитационное моделирование многовидовых разновозрастных лесных насаждений: автореф. дис. ... д-ра биол. наук (спец. 03.02.08). М.: Моск. гос. у-т леса, 2006. 32 c.

Шаниязова 3.П. Популяционная биология эфемеров Каракалпакии: автореф. дис. ... канд. биол. наук (спец. 03.02.08). М.: МГПУ им. В.И. Ленина, 1994. 16 с.

Шестакова А.А. Эколого-ценотические и флористические особенности организации бриобиоты на территории Нижегородской области: автореф. дис. ... канд. биол. наук (спец. 03.02.08). Нижний Новгород: ННГУ им. Н.И. Лобачевского, 2005. 28 с.

Шорина Н.И., Курченко Е.И., Григорьева Н.М. Алексей Александрович Уранов (19011974) // Самарская Лука: проблемы региональной и глобальной экологии. 2014. Т. 23. № 1. С. 93-129.

European Russian Forests. Their Current State and Features of Their History. Smirnova O., Bobrovsky M., Khanina L. (eds.). Dordrecht: Springer Nature. 2017. 566 p.

Grime J.P. Plant strategies and vegetation processes. N.Y. 1979. 222 p.

Kalyakin V.N., Turubanova S.A., Smirnova O.V. The origin and development of the East European taiga in late Cenozoic // Russian Journal of Ecosystem Ecology. 2016. Vol. 1. No 1. P. 126. DOI: $10.21685 / 2500-0578-2016-1-2$.

Smirnova O.V., Geraskina A.P., Aleinikov A.A. The concept "complementarity" as the basis for model and nature reconstruction of potential biota in the current climate // Russian Journal of Ecosystem Ecology. 2018. Vol. 3. No 3. P. 1-21. DOI: 10.21685/2500-0578-2018-3-1.

Smirnova O.V., Toropova N.A. Potential ecosystem cover - a new approach to conservation biology // Russian Journal of Ecosystem Ecology. 2016. Vol. 1. No 1. P. 1-16. DOI: 10.21685/25000578-2016-1-1.

\section{REFERENCES}

Alejnikov A.A., Sostojanie populjacii i sredopreobrazujushhaja dejatel'nost' bobra evropejskogo na territorii zapovednika «Brjanskij les» i ego ohrannoj zony: avtoref. dis. ... kand. biol. nauk (Population status and environmental activity of the European beaver on the territory of the reserve "Bryansk forest" and its protection zone. Extended abstract of Candidate's thesis). Tol'jatti: In-t jekologii Volzhskogo bassejna RAN, 2010. 22 p.

Argunova M.V., Ekologicheskoe obrazovanie v interesah ustojchivogo razvitija kak nadpredmetnoe napravlenie modernizacii shkol'nogo obrazovanija: avtoref. dis. ... d-ra. ped. nauk (Environmental education for sustainable development as a non-objective direction of modernization of school education. Extended abstract of Doctor's thesis). Moscow: Mosk. gos. obl. un-t, 2010. 47 p. 
Argunova M.V., Populjacionnaja organizacija dubovo-grabovyh lesov Zapadnoj Ukrainy $i$ optimizacija ih struktury: avtoref. dis. ... kand. biol. nauk (Population organization of oak-hornbeam forests of Western Ukraine and optimization of their structure. Extended abstract of Candidate's thesis). Moscow: MGPU im. V.I. Lenina, 1993. 16 p.

Barinova M.A., Vlijanie vodohranilishha na sinuzii zelenyh mhov doliny Giljuja: avtoref. dis. ... kand. biol. nauk (The reservoir effect on sinusoi green mosses of the valley Gilya. Extended abstract of Candidate's thesis). Moscow: MGPU im. V.I. Lenina, 1997. 16 p.

Bobrovskaja N.E., Formirovanie struktury kron listvennyh i hvojnyh derev'ev v ontogeneze: avtoref. dis. ... kand. biol. nauk (Formation of crown structure of deciduous and coniferous trees in ontogenesis. Extended abstract of Candidate's thesis). Moscow: MGPU, 2001. 19 p.

Bobrovskij M.V., Bioticheskie $i$ antropogennye faktory dolgovremennoj dinamiki lesnyh pochv Evropejskoj Rossii: avtoref. dis. ... d-ra biol. nauk (Biotic and anthropogenic factors of longterm dynamics of forest soils in European Russia. Extended abstract of Doctor's thesis). Vladimir: im. A.G. i N.G. Stoletovyh, 2013. 48 p.

Bobrovskij M.V., Raznoobrazie rastitel'nosti i pochv zapovednika «Kaluzhskie zaseki» i ego svjaz's tradicionnym prirodopol'zovaniem: avtoref. dis. ... kand. biol. nauk (Diversity of vegetation and soils of the reserve "Kaluga Zaseki" and its connection with traditional nature management. Extended abstract of Candidate's thesis). Moscow: MGPU, 2004. 23 p.

Bogdanova N.G., Formirovanie travjanogo pokrova hvojno-shirokolistvennyh i shirokolistvennyh lesov v hode vosstanovitel'nyh sukcessij v Nerusso-Desnjanskom poles'e: avtoref. dis. ... kand. biol. nauk (The formation of grass cover coniferous and deciduous forests during the restoration successions in Nerussa-Desna Polesye). Moscow: MGPU, 2006. 21 p.

Braslavskaja T.Ju., Biologicheskoe raznoobrazie i dinamika rastitel'nosti v pojme maloj reki Juzhnogo Nechernozem'ja (na primere r. Nerussa, Brjanskaja obl.): avtoref. dis. ... kand. biol. nauk (Biological diversity and vegetation dynamics in the floodplain of the small river of the southern nonChernozem region (by the example of the Neruss river, Bryansk region). Extended abstract of Candidate's thesis). Moscow: MGPU, 2001.21 p.

Cenopopuljacii rastenij (ocherki populjacionnoj biologii) (Plant coenopopulations (essays on population biology)). Moscow: Nauka, 1988, 184 p.

Cenopopuljacii rastenij (osnovnye ponjatija i struktura) (Plant coenopopulations (basic concepts and structure)), Moscow: Nauka, 1976, 217 p.

Cenopopuljacii rastenij (razvitie i vzaimootnoshenija) (Plant coenopopulations (development and relationships)), Moscow: Nauka, 1977, 135 p. 
Chumachenko S.I., Biojekologicheskaja model' raznovozrastnogo lesnogo cenoza: avtoref. dis. ... kand. biol. nauk (Bioecological model of uneven-aged forest cenosis. Extended abstract of Candidate's thesis), Moscow: MGPU im. V.I. Lenina, 1993, 16 p.

Chumachenko S.I., Imitacionnoe modelirovanie mnogovidovyh raznovozrastnyh lesnyh nasazhdenij: avtoref. dis. ... d-ra biol. nauk (Simulation modeling of multi-species multi-age forest stands. Extended abstract of Doctor's thesis). Moscow: Mosk. gos. u-t lesa, 2006, 32 p.

Dinamika cenopopuljacij rastenij (Dynamics of plant coenopopulations). Moscow: Nauka, 1985, $208 \mathrm{p}$.

European Russian Forests. Their Current State and Features of Their History. Smirnova O., Bobrovsky M., Khanina L. (eds.). Dordrecht: Springer Nature, 2017. 566 p.

Evstigneev O.I., Fitocenotipy i otnoshenie listvennyh derev'ev $k$ svetu: avtoref. dis. ... kand. biol. nauk (Fitocenotype and the relation of deciduous trees to light. Extended abstract of Candidate's thesis). Moscow: MGPI im. V.I. Lenina, 1990. 17 p.

Evstigneev O.I., Mehanizmy podderzhanija biologicheskogo raznoobrazija lesnyh biogeocenozov: avtoref. dis. ... d-ra biol. nauk (Mechanisms of maintenance of biological diversity of forest biogeocenoses. Extended abstract of Doctor's thesis). Nizhnij Novgorod: NNGU im. N.I. Lobachevskogo, 2010. 48 p.

Evstigneev O.I., Populjacionnye strategii vidov derev'ev (Population strategies of tree species), Vostochnoevropejskie lesa: istorija v golocene i sovremennost'. Moscow: Nauka, 2004, Vol. 1. pp. 176-205.

Evstigneev O.I., Didenko E.G., Populjacionnye strategii vidov kustarnikov (Population strategies of shrub species), Vostochnoevropejskie lesa: istorija v golocene i sovremennost' (Eastern European forests: history in Holocene and contemporaneity). Moscow: Nauka, 2004, Vol. 2, pp. 205224.

Grime J.P., Plant strategies and vegetation processes, N.Y., 1979, 222 p.

Haritonenkov M.A., Rol' antropogennogo faktora v formirovanii rastitel'nogo pokrova juga Zapadno-Sibirskoj ravniny $v$ jepohu tradicionnogo prirodopol'zovanija (s pozdnego paleolita do konca XIX v.): avtoref. dis. ... kand. biol. nauk (The role of anthropogenic factor in the formation of vegetation cover of the South of the West Siberian plain in the era of traditional nature management (from the late Paleolithic to the end of the XIX century). Extended abstract of Candidate's thesis), Moscow: Mosk. gos. obl. un-t, 2012, 25 p.

Istomina I.I., Kvazisenil'nost' i ee rol'v zhizni drevesnyh rastenij: avtoref. dis. ... kand. biol. nauk (Quasi-senility and its role in the life of woody plants. Extended abstract of Candidate's thesis), Moscow: MGPU im. V.I. Lenina, 1993. 16 p. 
Kalyakin V.N., Turubanova S.A., Smirnova O.V., The origin and development of the East European taiga in late Cenozoic, Russian Journal of Ecosystem Ecology, 2016, Vol. 1, No 1, pp. 126, DOI: $10.21685 / 2500-0578-2016-1-2$.

Kiseleva L.L., Jekologo-floristicheskij analiz jekotonnyh soobshhestv central'noj lesostepi: avtoref. dis. ... kand. biol. nauk (Ecological and floristic analysis of ecotonic communities of the Central forest-steppe. Extended abstract of Candidate's thesis), Moscow: MGPU im. V.I. Lenina, 1994, 16 p.

Korotkov V.N., Demutacionnye processy v ostrovnyh lesnyh massivah (na primere GIZL «Gorki Leninskie» i Kanevskogo zapovednika): avtoref. dis. ... kand. biol. nauk (Demutation processes in island forests (on the example GISL Gorki Leninskie and Kanev nature reserve). Extended abstract of Candidate's thesis), Moscow: MGPU im. V.I. Lenina, 1993, 16 p.

Korotkov V.N., Novaja paradigma v lesnoj jekologii (New paradigm in forest ecology), Biologicheskie nauki, 1991, No 8, pp. 7-20.

Lugovaja D.L., Rol' jekotopicheskih $i$ antropogenny faktorov $v$ formirovanii vidovogo $i$ strukturnogo raznoobrazija juzhnotaezhnyh lesov (vostok Kostromskoj oblasti): avtoref. dis. ... kand. biol. nauk (The role of ecotopic and anthropogenic factors in the formation of species and structural diversity of South taiga forests (East of Kostroma region). Extended abstract of Candidate's thesis), Moscow: MGPU, 2008, 28 p.

Nedoseko O.I., Ontomorfogenez Salix pentandra L., Salix caprea L., Salix cinerea L.: avtoref. dis. ... kand. biol. nauk (The ontomorphogenesis Salix pentandra L., Salix caprea L., Salix cinerea L. Extended abstract of Candidate's thesis), Moscow: MGPU im. V.I. Lenina, 1993, 16 p.

Nedoseko O.I., Stanovlenie zhiznenny form i arhitektoniki kron boreal'nyh vidov iv podrodov Salix i Vetrix Dumort. v ontogeneze: avtoref. dis. ... d-ra biol. nauk (Formation of life forms and architectonics of crowns of boreal species of willows of subgenera Salix and Vetrix Dumort. in ontogenesis. Extended abstract of Doctor's thesis), Moscow: MSHA im. K.A. Timirjazeva, 2018, 43 p.

Ocenka i sohranenija bioraznoobrazija lesnogo pokrova v zapovednikah Evropejskoj Rossii (Assessment and conservation of forest cover biodiversity in reserves of European Russia), Moscow: Nauchnyj mir, 2000, 196 p.

Ontogenez i vozrastnoj sostav populjacij cvetkovyh rastenij (Ontogenesis and age composition of flowering plant populations), Moscow: Nauka, 1967, $156 \mathrm{p}$.

Popov S.Ju., Struktura i dinamika rastitel'nosti Kerzhenskogo zapovednika: avtoref. dis. ... kand. biol. nauk (Structure and dynamics of vegetation of Kerzhensky reserve. Extended abstract of Candidate's thesis), Moscow: MGPU, 2008, 20 p. 
Rabotnov T.A., Zhiznennyj cikl mnogoletnih travjanistyh rastenij v lugovyh cenozah (Life cycle of perennial herbaceous plants in meadow cenoses), Trudy BIN ANSSSR, Ser. 3, Geobotanika, 1950, Vol. 6, pp. 7-204.

Ramenskij L.G., O principial'nyh ustanovkah, osnovnyh ponjatijah i terminah proizvodstvennoj tipologii zemel', geobotaniki i jekologii (On fundamental principles, basic concepts and terms of production typology of land, geobotany and ecology), Sovetskaja botanika, 1935, No 4, pp. 25-41.

Ripa S.I., Populjacionno-cenoticheskij analiz gornyh bukovyh $i$ smeshannyh lesov Ukrainskih Karpat: avtoref. dis. ... kand. biol. nauk (Population-cenotic analysis of mountain beech and mixed forests of the Ukrainian Carpathians. Extended abstract of Candidate's thesis), Moscow: MGPU im. V.I. Lenina, 1997, 16 p.

Romanovskij A.M., Osobennosti ontogeneza i fitocenoticheekaja rol' eli evropejskoj v lesah Nerusso-Desnjanskogo poles'ja: avtoref. dis. ... kand. biol. nauk (Features of ontogenesis and phytocenotic role of spruce in the forests Nerussa-Desna Polesye. Extended abstract of Candidate's thesis), Moscow: MGPU, 2006, 18 p.

Samohina T.Ju., Struktura i spontannaja dinamika hvojno-shirokolistvennyh lesov Srednego Urala: avtoref. dis. ... kand. biol. nauk (Structure and spontaneous dynamics of coniferous broadleaved forests of the Middle Urals. Extended abstract of Candidate's thesis), M.: MGPU im. V.I. Lenina, 1997, 16 p.

Sarycheva E.P., Strukturnoe i vidovoe raznoobrazie chernool'hovyh lesov centra evropejskoj Rossii (na primere zapovednikov «Brjanskij les» $i$ «Voroninskij»): avtoref. dis. ... kand. biol. nauk (Structural and species diversity of black alder forests in the center of European Russia (on the example of reserves «Bryansk forest» and «Voroninsky») Extended abstract of Candidate's thesis), M.: MGPU, 2000, 16 p.

Shanijazova Z.P., Populjacionnaja biologija jefemerov Karakalpakii: avtoref. dis. ... kand. biol. nauk (Population biology of the ephemera of Karakalpakstan. Extended abstract of Candidate's thesis), Moscow: MGPU im. V.I. Lenina, 1994, 16 p.

Shestakova A.A., Jekologo-cenoticheskie i floristicheskie osobennosti organizacii briobioty na territorii Nizhegorodskoj oblasti: avtoref. dis. ... kand. biol. nauk (Ecological-cenotic and floristic features of the organization of mosses in the Nizhny Novgorod region. Extended abstract of Candidate's thesis), Nizhnij Novgorod: NNGU im. N.I. Lobachevskogo, 2005, 28 p.

Shorina N.I., Kurchenko E.I., Grigor'eva N.M., Aleksej Aleksandrovich Uranov (1901-1974) (Alexei Alexandrovich Uranov, 1901-1974) // Samarskaja Luka: problemy regional'noj i global'noj jekologii, 2014, Vol. 23, No 1, pp. 93-129. 
Smirnova O.V., Populjacionnaja organizacija biocenoticheskogo pokrova lesnyh landshaftov (Population organization of biocenotic cover of forest landscapes), Uspehi sovrem. biol., 1998, Vol. 118, No 2, pp. 148-165.

Smirnova O.V., Populjacionnaja organizacija biogeocenoticheskogo pokrova lesnyh territorij (Population organization of biogeocenosis cover of forest territories), Ocenka $i$ sohranenija bioraznoobrazija lesnogo pokrova v zapovednikah Evropejskoj Rossii (Assessment and conservation of forest cover biodiversity in reserves of European Russia), Moscow: Nauchnyj mir, 2000, pp. 1422.

Smirnova O.V., Povedenie vidov $i$ funkcional'naja organizacija travjanogo pokrova shirokolistvennyh lesov (na primere ravninnyh shirokolistvennyh lesov Evropejskoj chasti SSSR $i$ lipnjakov Sibiri): dis. ... d-ra biol. nauk (Behavior of species and functional organization of grass cover of broad-leaved forests (on the example of flat broad-leaved forests of the European part of the USSR and Linden forests of Siberia). Doctor's thesis), Leningrad: LGU im. A.A. Zhdanova, 1983, $685 \mathrm{p}$.

Smirnova O.V., Povedenie vidov i funkcional'naja organizacija travjanogo pokrova shirokolistvennyh lesov Evropejskoj chasti SSSR (Behavior of species and functional organization of grass cover of deciduous forests of the European part of the USSR), Bjul. MOIP. Otd. biol., 1980, Vol. 85, No. 5, pp. 53-67.

Smirnova O.V., Struktura travjanogo pokrova shirokolistvennyh lesov (Grass cover structure of broad-leaved forests), Moscow: Nauka, 1987, 208 p.

Smirnova O.V., Zhiznennye cikly, chislennost' $i$ vozrastnoj sostav populjacij osnovnyh komponentov travjanogo pokrova dubrav: dis. ... kand. biol. nauk (Life cycles, number and age composition of populations of the main components of oak grass cover. Candidate's thesis), Moscow: MGPI im. V.I. Lenina, 1968, 285 p.

Smirnova O.V., Bakun E.Ju., Turubanova S.A., Predstavlenie o potencial'nom i vosstanovlennom rastitel'nom pokrove lesnogo pojasa Vostochnoj Evropy (Understanding of the potential and restored vegetation cover of the forest belt of Eastern Europe), Lesovedenie, 2006, No 1, pp. 22-33.

Smirnova O.V., Bobrovskij M.V., Vozdejstvie proizvodjashhego hozjajstva na sostav i strukturu lesnogo pokrova (The impact of the producing economy on the composition and structure of forest cover), Ocenka i sohranenija bioraznoobrazija lesnogo pokrova v zapovednikah Evropejskoj Rossii (Assessment and conservation of forest cover biodiversity in reserves of European Russia), Moscow: Nauchnyj mir, 2000, pp. 22-26.

Smirnova O.V., Chistjakova A.A., Analiz fitocenoticheskih potencij nekotoryh drevesnyh vidov shirokolistvennyh lesov Evropejskoj chasti SSSR (Analysis of phytocenotic potencies of some 
woody species of broad-leaved forests of the European part of the USSR), Zhurn. obshh. biol., 1980, Vol. 41, No 3, pp. 350-362.

Smirnova O.V., Chistjakova A.A., Drobysheva T.I., Cenopopuljacionnyj analiz i prognozy razvitija dubovo-grabovyh lesov Ukrainy (Cenopopulation analysis and forecasts of development of oak-hornbeam forests in Ukraine), Zhurn. obshh. biol., 1987, Vol. 48, No 2, pp. 200-212.

Smirnova O.V., Chistjakova A.A., Popadjuk R.V., Populjacionnye mehanizmy dinamiki lesnyh cenozov (Population mechanisms of the dynamics of forest cenoses). Biologicheskie nauki, 1989, No 11, pp. 48-58.

Smirnova O.V., Chistjakova A.A., Popadjuk R.V., Evstigneev O.I., Korotkov V.N., Mitrofanova M.V., Ponomarenko E.V., Populjacionnaja organizacija rastitel'nogo pokrova lesnyh territorij (na primere shirokolistvennyh lesov evropejskoj chasti SSSR) (Population organization of vegetation cover of forest areas (on the example of broad-leaved forests of the European part of the USSR)), Pushhino: ONTI Nauchnyj centr biol. issledovanij AN SSSR, 1990, 92 p.

Smirnova O.V., Chistjakova A.A., Ripa S.I., Lysyh N.I., Populjacionnaja organizacija bukovyh lesov Zakarpat'ja (Population organization of beech forests in Transcarpathia), Bjul. MOIP. Otd. biol., 1989, Vol. 94, No 5, pp. 78-91.

Smirnova O.V., Geraskina A.P., Aleinikov A.A., The concept "complementarity" as the basis for model and nature reconstruction of potential biota in the current climate, Russian Journal of Ecosystem Ecology, 2018, Vol. 3, No 3, pp. 1-21, DOI: 10.21685/2500-0578-2018-3-1.

Smirnova O.V., Kaljakin V.N., Turubanova S.A., Bobrovskij M.V., Sovremennaja zonal'nost' Vostochnoj Evropy kak rezul'tat preobrazovanija pozdneplejstocenovogo kompleksa kljuchevyh vidov (Modern zoning of Eastern Europe as a result of transformation of the late Pleistocene complex of key species), Mamont i ego okruzhenie: 200 let izuchenija (Mammoth and its environment: 200 years of study), Moscow: Geos, 2001a, pp. 200-208.

Smirnova O.V., Lugovaja D.L., Prokazina T.S., Model'naja rekonstrukcija vosstanovlennogo lesnogo pokrova taezhnyh lesov (Model reconstruction of the restored forest cover of taiga forests), Uspehi sovrem. biol., 2013, Vol. 133, No 2, pp. 164-177.

Smirnova O.V., Popadjuk R.V., Chistjakova A.A., Populjacionnye metody opredelenija minimal'noj ploshhadi lesnogo cenoza (Population methods for determining the minimum area of forest cenosis), Bot. zhurn., 1988, Vol. 73, No 10, pp. 1423-1433.

Smirnova O.V., Popadjuk R.V., Janickaja T.O., Korotkov V.N., Puti vosstanovlenija populjacionnoj struktury i vidovogo raznoobrazija v lesnyh demutacionnyh kompleksah (Ways of restoration of population structure and species diversity in forest demutation complexes), Biologicheskie nauki, 1992, No 5, pp. 7-25. 
Smirnova O.V., Toropova N.A., Potencial'naja rastitel'nost' i potencial'nyj jekosistemnyj pokrov (Potential vegetation and potential ecosystem cover), Uspehi sovrem. biol., 2016, Vol. 136. No 2, pp. 199-211.

Smirnova O.V., Toropova N.A., Potential ecosystem cover - a new approach to conservation biology, Russian Journal of Ecosystem Ecology, 2016, Vol. 1, No 1, pp. 1-16, DOI: 10.21685/25000578-2016-1-1.

Smirnova O.V., Toropova N.A., Sukcessija i klimaks kak jekosistemnyj process (Potential vegetation and potential ecosystem cover), Uspehi sovrem. biol., 2008, Vol. 128, No 2, pp. 129-144.

Smirnova O.V., Turubanova S.A., Formirovanie i razvitie Vostochnoevropejskih shirokolistvennyh lesov $\mathrm{v}$ golocene (Formation and development of Eastern European broadleaf forests in the Holocene), Bjul. MOIP. Otd. biol., 2003, Vol. 108, No 2, pp. 32-40.

Smirnova O.V., Turubanova S.A., Bobrovskij M.V., Korotkov V.N., Hanina L.G., Rekonstrukcija istorii biocenoticheskogo pokrova Vostochnoj Evropy i problema podderzhanija biologicheskogo raznoobrazija (Reconstruction of the history of the biocenotic cover of Eastern Europe and the problem of maintaining biological diversity), Uspehi sovrem. biol., 2001b, No 2, pp. 144-159.

Smirnova O.V., Voznjak R.R., Evstigneev O.I., Korotkov V.N., Nosach N.Ja., Popadjuk R.V., Samojlenko V.K., Toropova N.A., Populjacionnaja diagnostika i prognozy razvitija zapovednyh lesnyh massivov (na primere Kanevskogo zapovednika) (Population diagnostics and forecasts of development of protected forests (on the example of Kanev reserve)), Bot. zhurn. 1991, Vol. 76, No 6, pp. 860-871.

Smirnova O.V., Zaugol'nova L.A., Popadjuk R.V., Populjacionnaja koncepcija v biocenologii (Population concept in biotsenology), Zhurn. obshh. biol. 1993, Vol. 54, No 4, pp. 438-448.

Smirnova Ol'ga Vsevolodovna // Intellektual'naya Sistema Tematicheskogo Issledovaniya Naukometricheskih dannyh (Intelligent System case Studies Scientometric data), available at: http://istina.msu.ru/profile/sov1933/.

Sugorkina N.S., Ontogenez i osobennosti populjacionnoj biologii vidov roda geran': avtoref. dis. ... kand. biol. nauk (Ontogenesis and peculiarities of population biology of geranium species. Extended abstract of Candidate's thesis). Moscow: MGPI im. V.I. Lenina, 1989, 17 p.

Turubanova S.A., Jekologicheskij scenarij istorii formirovanija zhivogo pokrova Evropejskoj Rossii i sopredel'nyh territorij na osnove rekonstrukcii arealov kljuchevyh vidov zhivotnyh i rastenij: avtoref. dis. ... kand. biol. nauk (Ecological scenario of the history of the formation of the living cover of European Russia and adjacent territories on the basis of the reconstruction of the habitats of key species of animals and plants. Extended abstract of Candidate's thesis), Moscow: In-t biol. Komi nauchn. centra Ural'skogo otd. RAN, 2002, 23 p. 
Voprosy morfogeneza cvetkovyh rastenij i stroenija ih populjacij (Morphogenesis of flowering plants and the structure of their populations). Moscow: Nauka, 1968, $234 \mathrm{p}$.

Vostochnoevropejskie lesa: istorija v golocene i sovremennost' (Eastern European forests: history in Holocene and contemporaneity). Moscow: Nauka, 2004a, Vol. 1, 479 p.

Vostochnoevropejskie lesa: istorija v golocene i sovremennost' (Eastern European forests: history in Holocene and contemporaneity). Moscow: Nauka, 2004b, Vol. 2, 575 p.

Vostochnoevropejskie shirokolistvennye lesa (Eastern European broadleaf forests). Moscow: Nauka, 1994, 364 p.

Vozrastnoj sostav populjacij cvetkovyh rastenij $v$ svjazi s ih ontogenezom (Age composition of flowering plant populations due to their ontogenesis). Moscow: MGPI im. V.I. Lenina, 1974, 216 p.

Zaprudina M.V., Mikromozaichnaja organizacija travjano-kustarnichkovogo i mohovogo pokrova srednetaezhnyh temnohvojnyh lesov Urala: avtoref. dis. ... kand. biol. nauk (Micromosaic organization of grass-shrub and moss cover of middle taiga dark coniferous forests of the Urals. Extended abstract of Candidate's thesis). Moscow: MGPU, M., 2012, 23 p.

Zaugol'nova L.A., Zhukova L.A., Popadjuk R.V., Smirnova O.V., Kriticheskoe sostojanie cenopopuljacij rastenij (The critical state of plant coenopopulations), Problemy ustojchivosti biologicheskih sistem. Moscow: Nauka, 1992, pp. 51-59.

Zaugol'nova L.B., Struktura cenopopuljacij semennyh rastenij i problemy ih monitoringa: dis. ... d-ra biol. nauk (Structure of seed plant coenopopulations and problems of their monitoring. Doctor's thesis). SPb: SPb gos. un-t, 1994, 70 p.

Zaugol'nova L.B., Svjaz' vozrastnogo spektra cenopopuljacij s biologicheskimi svojstvami vida (Relation of age spectrum of coenopopulations with biological properties of a species), In: Vozrastnoj sostav populjacij cvetkovyh rastenij v svjazi s ih ontogenezom (Age composition of flowering plant populations due to their ontogenesis). Moscow: MGPI im. V.I. Lenina, 1974, pp. 3855.

Zaugol'nova L.B., Smirnova O.V., Vozrastnaja struktura cenopopuljacij mnogoletnih rastenij i ee dinamika (Age structure of perennial plant coenopopulations and its dynamics), Zhurn. obshh. biol. 1978. Vol. 39, No 6, pp. 849-858.

Zaugol'nova L.B., Smirnova O.V., Komarov A.S., Hanina L.G., Monitoring fitopopuljacij (Monitoring of phytopopulation), Uspehi sovrem. biol. 1993, Vol. 113, No 4, pp. 402-414.

Zhukova L.A., Mir prinadlezhit optimistam (The world belongs to the optimists), Polivariantnost' razvitija organizmov, populjacij i soobshhestv. Joshkar-Ola: Mar. gos. un-t, 2006. pp. 229-278. 


\title{
PROFESSOR OLGA V. SMIRNOVA'S SYSTEM OF VIEWS IN FOREST ECOSYSTEM
}

\section{ECOLOGY}

\author{
O.I. Evstigneev ${ }^{1,3^{*}}$, V.N. Korotkov ${ }^{2}$ \\ ${ }^{1}$ State Nature Biosphere Reserve "Bryanskii Les", Nerussa Station, Bryansk Oblast, 242180, Russia \\ ${ }^{2} Y$ u. A. Israel Institute of Global Climate and Ecology, 20B Glebovskaya st., Moscow, 107258, \\ Russia
}

${ }^{3}$ Center for Forest Ecology and Productivity of the RAS, Profsoyuznaya st. 84/32 bldg. 14, Moscow,

$$
\text { 117997, Russia }
$$

*E-mail:quercus_eo@mail.ru

Received 16 September 2019

Professor Olga V. Smirnova, Doctor of Biological Sciences, is a prominent scientist in the field of plant demography, population biology and forest ecosystem ecology. Professor Smirnova's edifice is based on ideas about the leading role of plant and animal populations in the organisation of the biogeocenotic cover. In this case, it is implied that a continuous turnover of generations in populations of edificators (key species) is necessary to maintain the species and structural diversity of communities and ensure their sustainability. This system of views was formed under the influence of Professor Alexey A. Uranov. The development of these ideas was consistent and gradual. First, Professor Smirnova studied the biology of different plant species life forms. Examining their individual development, with identification of ontogenetic stages, is necessary for demographic research. She then developed the theory of coenopopulations as supraorganismal systems, which can self-sustain under different conditions. Finally, she developed the doctrine of biogeocenosis as a system of interacting populations and created the concept of anthropogenic transformation of the forest cover in the Holocene. Her contributions helped researchers to understand the mechanisms of the formation of modern zonality that are due to human activity.

Key words: plant biological age, plant population strategy, coenopopulation, edificator, forest biogeocenology, modern zonality, historical ecology

Рецензент: к.б.н., с.н.с. Горнов А.В. 